

\title{
Runoff evolution according to land use change in a small Sahelian catchment
}

Luc Descroix, Michel Esteves, K. Souley Yero, Jean-Louis Rajot, M. Malam Abdou, S. Boubkraoui, Jean-Marc Lapetite, N. Dessay, I. Zin, O. Amogu, et al.

\section{To cite this version:}

Luc Descroix, Michel Esteves, K. Souley Yero, Jean-Louis Rajot, M. Malam Abdou, et al.. Runoff evolution according to land use change in a small Sahelian catchment. Hydrology and Earth System Sciences Discussions, 2011, 8 (1), pp.1569-1607. 10.5194/hessd-8-1569-2011 . ird-02153334

\section{HAL Id: ird-02153334 \\ https://hal.ird.fr/ird-02153334}

Submitted on 12 Jun 2019

HAL is a multi-disciplinary open access archive for the deposit and dissemination of scientific research documents, whether they are published or not. The documents may come from teaching and research institutions in France or abroad, or from public or private research centers.
L'archive ouverte pluridisciplinaire HAL, est destinée au dépôt et à la diffusion de documents scientifiques de niveau recherche, publiés ou non, émanant des établissements d'enseignement et de recherche français ou étrangers, des laboratoires publics ou privés. 
Hydrol. Earth Syst. Sci. Discuss., 8, 1569-1607, 2011 www.hydrol-earth-syst-sci-discuss.net/8/1569/2011/ doi:10.5194/hessd-8-1569-2011

(C) Author(s) 2011. CC Attribution 3.0 License.
Hydrology and Earth System Sciences Discussions

This discussion paper is/has been under review for the journal Hydrology and Earth System Sciences (HESS). Please refer to the corresponding final paper in HESS if available.

\section{Runoff evolution according to land use change in a small Sahelian catchment}

L. Descroix ${ }^{1}$, M. Esteves ${ }^{1}$, K. Souley Yéro ${ }^{1}$, J.-L. Rajot ${ }^{2}$, M. Malam Abdou ${ }^{3}$, S. Boubkraoui ${ }^{1}$, J. M. Lapetite ${ }^{1}$, N. Dessay ${ }^{5}$, I. Zin ${ }^{6}$, O. Amogu ${ }^{1}$, A. Bachir ${ }^{3}$, I. Bouzou Moussa ${ }^{3}$, E. Le Breton ${ }^{4}$, and I. Mamadou ${ }^{4}$

${ }^{1}$ IRD/UJF-Grenoble 1/CNRS/G-INP, LTHE UMR 5564, Grenoble, 38041, France

${ }^{2}$ IRD - BIOEMCO /LISA, Université Paris Est Créteil, Créteil, France

${ }^{3}$ Université Abdou Moumouni, Departement de géographie, Niamey, Niger

${ }^{4}$ LGP-CNRS, Meudon Bellevue, France

${ }^{5}$ UMR ESPACE/IRD, Montpellier, France

${ }^{6}$ LTHE-G-INP, BP 53, 38041 Grenoble cedex 9, France

Received: 14 December 2010 - Accepted: 27 December 2010 - Published: 1 February 2011 Correspondence to: L. Descroix (luc.descroix@ird.fr)

Published by Copernicus Publications on behalf of the European Geosciences Union.

\section{HESSD}

$8,1569-1607,2011$

Runoff evolution according to land use change

L. Descroix et al.

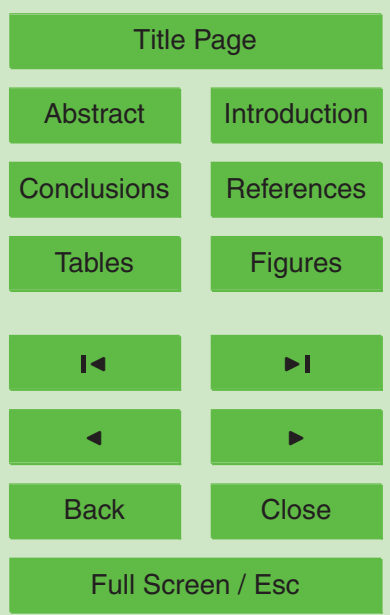

Printer-friendly Version

Interactive Discussion 


\section{Abstract}

Significant land use changes have been observed in West Africa, particularly in the Sahel region where climatic and demographic factors have led to a rise in cultivated areas, in recent decades. These changes caused strong modifications in the water 5 cycle and in river regimes.

By comparing the rainfall-runoff relationships for two periods (1991-1994 and 20042010) in two small neighbouring catchments (approx. $0.1 \mathrm{~km}^{2}$ each) of the Sahel, this study highlights the different hydrological consequences of land use change, particularly vegetation clearing and the consequent degradation of topsoil.

Runoff increased in the upper basin, while it decreased in the lower basin, due to a strong increase in in-channel infiltration. Flood peak durations have become shorter in the downstream part of the catchment due to the huge increase of runoff water transmission losses within the gullies.

Further study will consist of equipping one of the catchments with anti-erosion de15 vices (mainly "half-moons" and terraces) in order to evaluate the influence of antierosion devices on runoff and suspended load.

\section{Introduction}

Land use is rapidly changing in the Sahel. Natural vegetation had already almost disappeared in extended areas of Western Niger and Eastern Burkina Faso, replaced with crops and fallows. Furthermore, within the croplands, crop areas are increasing while fallow lands are decreasing Erosion processes entered a new stage where soil crusting linked to the shortening of fallow periods caused a significant increase in soil erosion and runoff within the region, accompanied with the consequent sedimentation downstream (Amogu, 2009; Le Breton, 2011; Mamadou, 2011). This led to the great extension of erosion-caused landforms: gullies and alluvial fans strongly increased in extension in the last decades.
HESSD

$8,1569-1607,2011$

\section{Runoff evolution \\ according to land use change}

L. Descroix et al.

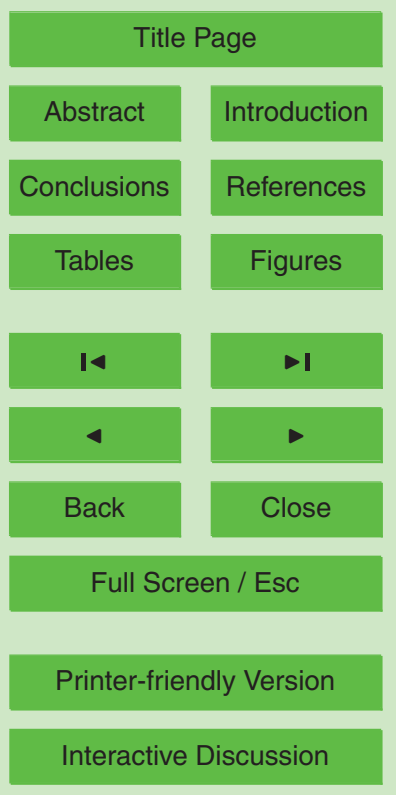

Interactive Discussion 
A significant increase in runoff coefficient is attributable to soil surface features developed in the hillslopes: crusted soils, erosion crusts, algal crusts, etc. (Casenave and Valentin, 1989).

Downstream these landforms constitute new infiltration areas (Descroix et al., 2009).

5 The new hillslope behaviour observed combine an increase in runoff at the local scale linked to soil structure degradation and crusting, and a decrease in runoff at the small catchment scale, attributable to a strong increase in transmission losses within the sandy deposit in gullies, the alluvial fans and spreading areas.

It was noticed that the Boserup theory ("more people, less erosion"), observed as an 10 existing model in some parts of Sub Saharan Africa, e.g. in Kenya (Tiffen et al., 1994) or in Ivory Coast (Demont and Jouve, 1999), does not apply for the moment in most of the Sahel, while the Hardin "tragedy of the commons" (Hardin, 1968) is partially observable, soil tenure being always under a traditional system without private property (Descroix et al., 2008). However, some examples of land reclamation successes show that the main trend is reversible, as it has been observed in the Central Plateau of Burkina Faso (Reij et al., 2005; Reij et al. 2009) and in Eastern parts of Niger (Larwanou et al., 2006; Di Vecchia et al., 2006; CRESA, 2006; Reij et al, 2009). In some cases, a rise in water table is attributable to the new spreading sills (near Keita in Niger, CRESA, 2006) and to land reclamation (Reij et al., 2005, 2009), while it is due to land degradation in some endorheic areas of the Sahel (Massuel et al., 2006; Leblanc et al., 2008; Descroix et al., 2009).

A strong land use change has led to a degradation of soils and vegetation in the Sahel during the last few decades. Some authors have found a "re-greening" of this region (Rasmussen et al., 2001; Anyamba and Tucker, 2005) others have observed 25 a decrease in albedo (Govaerts et al., 2008). However, Hein and De Ritter (2006) showed that using the RUE concept (rain use efficiency) helps to make satellite information more consistent with the numerous studies which highlighted a severe decrease in vegetation cover over the Sahel (Ada and Rockström, 1993; Loireau, 1998; Chinen, 1999; Le Breton, 2011; Leblanc et al., 2008 among others) and corroborates previous
HESSD

$8,1569-1607,2011$

\section{Runoff evolution \\ according to land use change}

L. Descroix et al.




observations of Hountondji et al. (2004) in Niger. Hiernaux et al. (2009) determined that in spite of land clearing, in some places, total biomass was increasing because of the higher value of millet biomass compared with that of natural vegetation. Numerous studies have demonstrated the influence of land cover changes on the hydrological 5 regime, at the point scale (Casenave and Valentin, 1989; Vandervaere et al., 1997, etc.), at the hillslope scale (Peugeot et al., 1997; Esteves and Lapetite, 2003), and at the basin scale (Albergel, 1987; Amani and Nguetora, 2002; Mahé et al., 2003; Descroix et al., 2009; Amogu, 2009; Amogu et al., 2010). There is a general agreement that increasing soil crusting has led to increasing runoff coefficients and a rise in runoff and flood irregularity in some parts of the region in spite of the decrease in rainfall. In some endorheic areas, this has led to a rise in the water table (Leduc et al., 2001; Leblanc et al., 2008; Favreau et al., 2009). Karambiri et al. (2003) showed that the surface features caused runoff and severe water erosion in a small catchment in Northern Burkina Faso.

15 The aim of this paper is to compare, in small Sahelian catchments, the land use changes and the water cycle evolution, especially in runoff production, during the last two decades, in order to determine whether land use change has caused hydrological changes at the small basin scale.

\section{Material and methods}

\subsection{Study area}

The Tondi Kiboro experimental catchments are located $70 \mathrm{~km}$ east of Niamey, Niger, on the western part of the lullemeden sedimentary basin (Fig. 1). In a landscape of dissected laterite-capped plateaus, the experimental site is located on a catena formed by a plateau with loamy-clayey soils and low slopes, the breakaway at the edge of this plateau (slopes $4-8 \%$ ) and a $2 \mathrm{~km}$-long sandy hillslope. The drainage network is composed of parallel gullies that concentrate the water running off from the plateau.

\section{HESSD}

$8,1569-1607,2011$

\section{Runoff evolution \\ according to land use change}

L. Descroix et al.

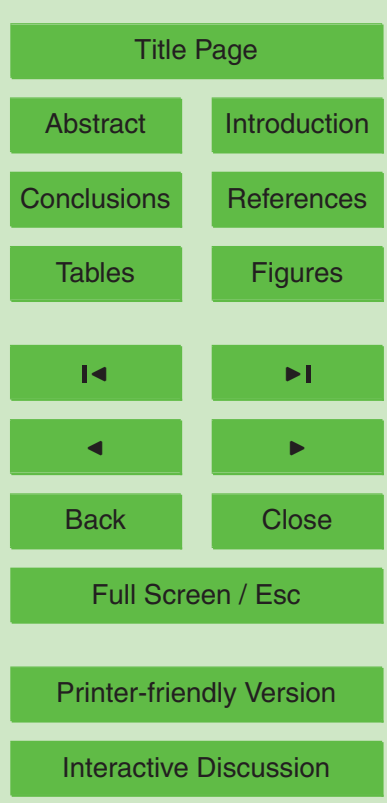


The major surface features identified in the catchment area are the following: tiger bush, bare soils stripes of this tiger bush, edge slope, on the plateau; sandy structured soils in crops and fallow and crusted soils in degraded crops and fallows on the sandy hillslope. The gullies include sandy deposit in increasing extension.

\subsection{Hydrological measurements}

Three basins near the village of Tondi Kiboro, in south-western Niger, were equipped and monitored from 1991 to 1994 and from 2004 to 2010. Two of them are nested ("amont" and "aval"); their respective sizes are $46800 \mathrm{~m}^{2}$ for the upper basin "amont" and $110540 \mathrm{~m}^{2}$ for the total one at the "aval" station (including the first one); the third one ("bodo"), is a $121800 \mathrm{~m}^{2}$ one, where the second observation period is only 4 years long (2007-2010). Stream gauge stations were equipped with "Chloe" (Elsyde, Paris, France) water level recorders during the first period, and "Thalimedes" (OTT, Kempten, Germany) water level recorders during the second period. Recording rain gauges were of the same type (PM3030 of Précis Mecanique, Bezons, France) for both periods, but data loggers were Oedipe type (Elsyde) during the first period and HoBo type (Onset, Pocusset, MA, the USA) during the second period.

These devices monitored rainfall and runoff and measured the duration of each running event.

\subsection{Soil moisture monitoring}

20 A set of devices was installed in order to monitor soil moisture in the gullies and in their surrounding areas, and was provided data from 2004 to 2010:

- soil moisture monitoring stations: soil moisture was measured at two places (gully and fallow) up to $3 \mathrm{~m}$ deep; soil suction and TDR (time domain reflectometry) sensors were used to monitor soil moisture in real-time;

- neutron probe access tubes provided monthly information (weekly during the rainy
HESSD

$8,1569-1607,2011$

\section{Runoff evolution \\ according to land use change}

L. Descroix et al.

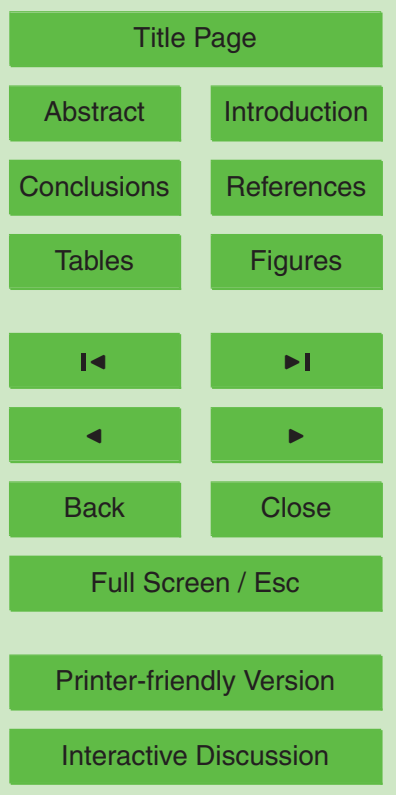


season) in 11 sites of the Tondi Kiboro basins; 4 of them were located in gullies and spreading areas, up to depths of $10 \mathrm{~m}$, and for two of them, up to depths of $25 \mathrm{~m}$;

- a recording piezometer was used to monitor the water table level under the main 5 gully (the mean depth of the water table was $46 \mathrm{~m}$ from the surface).

\subsection{Data analysis}

Land use mapping was carried out using aerial pictures, taken from a plane in 1993 and from a PIXY® (IRD) drone in 2007 . The precision and definition of pictures were sufficient to recognize all the vegetal formations without any doubts. The contours 10 were determined and digitalized using a GIS. The vegetation maps were made and compared using Arc GIS®.

NAZASM, an event-scale rainfall-runoff, conceptual-empirical model that calculates runoff amounts using a least square calibration method was presented by Nouvelot (1993) and described and used by Descroix et al. (2002), and Descroix et al. (2007) and

15 here in Appendix A. It allows determining the main hydrological processes by defining the impact of Antecedent Precipitation Index on the stream flows, as well as gives the soil current water content, the maximum runoff coefficient and the $\alpha$ parameter which is the soil water content depletion index. Chevalier (1983) estimated that the $\alpha$ parameter must be fixed as 0.5 in the Sahel and in most semi-arid areas. Recent studies in other tropical areas (northern Mexico) showed that the spatial and temporal variability of this parameter gives more information about the main runoff generation process at hillslopes and catchments scales (Descroix et al., 2007). It can range from 1 to very small values; under 0.01, it characterizes "Hewlettian" processes (saturation excess overland flow, also called Cappusian processes, Cappus, 1960; Hewlett, 1961), and 25 above 0.1, Hortonian areas (infiltration excess overland flow; Horton, 1933); between 0.1 and 0.01 , it indicates a mix of both kinds of processes. The main purpose of using NAZASM here is to determine whether the hydrodynamic behaviour of soils and basins studied here changed significantly in time.

\section{HESSD}

$8,1569-1607,2011$

\section{Runoff evolution according to land use change}

L. Descroix et al.

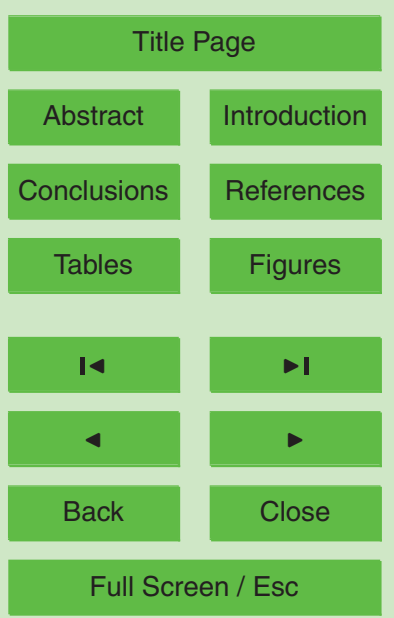

Printer-friendly Version

Interactive Discussion 
Trends, ruptures and persistence were analyzed using the Khronostat software (IRD, 2002). According to Kendall and Stuart (1943), the analysis of a time series is aimed at improving the understanding of the statistical mechanisms that have generated that series of observations. All authors agree on the breakdown of a typical time series into 5 four parts: a trend, a periodicity (more or less regular fluctuations around a trend), an autocorrelation or a memory effect (the magnitude of an observation depends on those of the previous observations and a random, non-systematic, irregular component, that is to say due to chance).

The KhronoStat software (IRD, 2002) was designed in the framework of a study 10 on climatic variability and is thus focused on the analysis of hydrometeorological series. The tests presented are extracted for the most part from the technical note $n^{\circ} 79$ "Climatic change of the World Meteorological Organization" (WMO, 1966), and from Kendall et Stuart (1943). The first tests (Buishand $u$ test and Pettit test) concern the random character of the series. If a series is declared not to be random, tests will be necessary to try and determine the non-random nature present in the series, for example the second tests for the detection of a jump at an unknown date (IRD, 2002). The Mann-Kendall "rank" test is used to determine whether the series has a trend or not; the Hubert test can proceed a segmentation of a series of data if this series includes trends and ruptures. The variables included in these trends and rupture analyses are the following: annual rainfall, runoff coefficient in 4 areas: the 3 basins (amont, aval and bodo) as well as the intermediary basin (the downstream area of aval basin, e.g. the part of aval basin not included in the amont catchment), and runoff depth in the same four areas.

\section{HESSD}

$8,1569-1607,2011$

\section{Runoff evolution according to land use change}

L. Descroix et al.

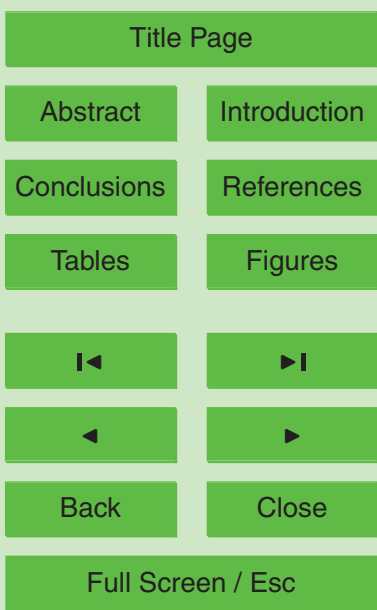

Printer-friendly Version

Interactive Discussion 


\section{Results}

\subsection{Land use changes}

HESSD

Figure 2 and Table 1 show the evolution of land cover over the Tondi Kiboro catchments. There is little variation on the small upper basin $\left(46800 \mathrm{~m}^{2}\right)$ but a significant decrease

5 in fallow lands in the lower part of the northern basin (aval). Fallow was replaced with degraded fallow, which is characterised by bare, mostly crusted soils. Degraded fallow , which covered $16 \%$ of the "aval" basin in 1993, reached $38 \%$ of the total area in 2007. In the same period, downstream of both "Bodo" and "Aval" catchments (and out of the map of Fig. 2) "sandy deposit" area doubled between 1993 and 2007. Upstream from the stream gauges, the sandy deposit are included in the "gully" class (Fig. 2). The "gullies" area did not change significantly during this period, but the volume of stored sand in the gully significantly increased in volume (field observations of the authors). Neither degraded fallow nor sandy deposit was observed in 1965 (a comparison was made based on CORONA pictures). These two classes have mostly replaced crops and fallows, which decreased strongly in spite of the increase in population.

In the Bodo catchment, the area of degraded fallow and crops increased from $22 \%$ to $33 \%$ between 1993 and 2007.

\subsection{Runoff coefficients}

Table 2 presents the rainfall, runoff and runoff coefficient per sub-basin in both periods 20 (1991-1994 and 2004-2010). Runoff coefficient values did not change at the outlet of the Aval basin; it did not increase at the seasonal time scale (non significant evolution). At the outlet of the upper basin (Amont station), on the contrary, the runoff coefficient was significantly higher on average during the 2004-2010 period (period 2) than during the 1991-1994 period (period 1), increasing from 0.36 to 0.43 . Almost the same evolution was observed in the Bodo catchment from period 1 to period 2 (here only 2007-2010), with the runoff coefficient increasing from 0.38 to 0.47 . It is noteworthy

\section{Runoff evolution according to land use change}

L. Descroix et al.

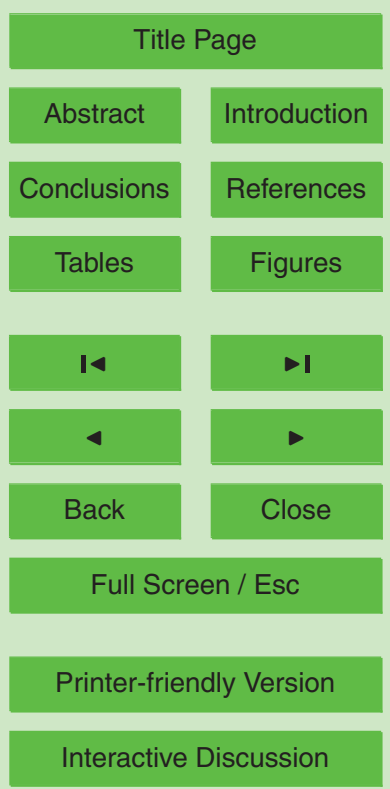


that in the nested basins (Amont and Aval stations) the changes in runoff coefficient occurred in the parts of the basin where land cover did not change significantly. Table 2 also indicates the equation of the rainfall/runoff relationship and the coefficient of determination $\left(R^{2}\right)$ taking into account the amount of rainfall $(P)$ and the square of this 5 amount $\left(P^{2}\right)$, commonly more adapted, because runoff coefficient increases generally with the total rainfall amount of a rain event, due to progressive soil saturation. At the event time scale and using the single rainfall/runoff relationship, there is a more significant increase in the runoff coefficient at the "amont" station (from 0.56 in 1991-1994 to 0.73 in 2004-2009) and at the "bodo" station (0.53 to 0.87) than at the "aval" station 10 (0.43 to 0.46$)$.

\subsection{Stream flow duration}

The duration of each flood is added in order to calculate the total duration of stream flows during a rainy season at each station. Table 3 gives the total duration of flows during period 1 and 2 . The duration of stream flows did not change significantly be15 tween the 2 periods in the upper "Amont" of the nested basins. On the contrary, it decreased significantly at the outlet of the basin (Aval station), decreasing from 28 to $18 \mathrm{~h}$ per year. And it decreased even more strongly at the "Bodo" station, from 63 to $26 \mathrm{~h}$ (period $2=2007-2010$ in this case). In the nested basins, the difference between the duration in the Amont and in the Aval station also increased, highlighting the fact that floods have a shorter duration downstream than on the upper part of the basin.

\subsection{Soil moisture monitoring}

Values of wetting front are very different from one land use to another. Every year during the 2004-2010 measuring period, the wetting front reaches more than $8 \mathrm{~m}$ in the bush part of tiger bush on the one hand (Table 4), due to the deep root system and dense vegetation, under gullies and spreading areas on the other hand, due to the sandy deposit where water is retained before infiltrating more deeply into the soil.
HESSD

$8,1569-1607,2011$

\section{Runoff evolution \\ according to land use change}

L. Descroix et al.



Printer-friendly Version

Interactive Discussion 
The second class of land use in terms of infiltration is constituted by all the other non degraded environments (Table 4): millet crops, fallow and areas surrounding the faidherbia albida trees ("gaos"); the last class (less than $1.5 \mathrm{~m}$ deepening of wetting front) is constituted by bare soils: the natural bare soils of the bare strip of tiger bush and the 5 degraded, crusted soils on fallow and cropped areas (ERO crust). The date of reaching the maximum value of soil water content does not vary in the same way: the bare soil areas of tiger bush reaches its maximum water content value first (around 22 August on average), then all the other land uses reach their maximum water content level in mid September, except the spreading areas where the wetting front continues up to 105 October on average.

The piezometric monitoring data show that during each rainy season, the wetting front reaches the water table some weeks after the beginning of the rain, due to the easy infiltration under gullies and spreading areas.

\subsection{Modelling the rainfall-runoff relationship using the NAZAS model}

15 The Nazas model (NAZASM) aims to improve the modelling of the rainfall-runoff relationship in catchments where both Hewlettian and Hortonian runoff generation processes are active. It is based on the Antecedent Precipitation Index. and calculates a theoretical soil moisture content at the beginning of the rainfall event. The model parameters are $H_{\max }$ the maximal soil water content (in $\mathrm{mm}$ ), $P_{\max }$, the maximal rainfall 20 amount which does not produce runoff, $K_{\max }$, the maximal runoff coefficient, and $\alpha$, the depletion index of soil moisture. Values of all the parameters are given in Table 5 and in Appendix B. A validation/calibration process of these parameters was conducted following a split sampling approach by constituting two sub-data series, the first one including the events $n, n+2, n+4, n+6$, etc, the second one including the events $n+1$, $25 n+3, n+5$, etc. The runs made with each one of these two data sets are compared in order to verify whether they produce similar results. The description of the NAZAS model is given in Appendix $A$.

\section{HESSD}

$8,1569-1607,2011$

\section{Runoff evolution \\ according to land use change}

L. Descroix et al.




It can be observed that:

- $H_{\max }$ decreased in all basins between period 1 and period 2, probably in relation with the soil degradation (that caused a decrease in the soil water holding capacity);

- An increase in $P_{\max }$, is measured between period 1 and 2 , likely attributable to the rise in infiltration under the gullies;

- Maximal runoff coefficient $K_{\text {max }}$, increased in both "bodo" and "amont" basins; this is possibly linked to soil crusting. It did not change (0.7) in the "aval" basin probably due to the strong infiltration rate in this reach of the creek;

- The $\alpha$ parameter increased in the 3 basins between period 1 and period 2: this evolution is likely to be related to the decrease in the soil water holding capacity (caused by the crusting processes) and the increase in Hortonian "infiltration excess" type runoff.

\subsection{Trends and ruptures}

Despite the time shortness of the data, an analysis of trends, persistence and ruptures was carried out for rainfall, the runoff coefficient and the runoff depth in the four catchments: amont, Aval and the intermediary catchment, e.g. the part of the aval catchment located downstream of the amont catchment stream gauge in the northern basin, and the Bodo catchment.

\section{HESSD}

8, 1569-1607, 2011

\section{Runoff evolution according to land use change}

L. Descroix et al.

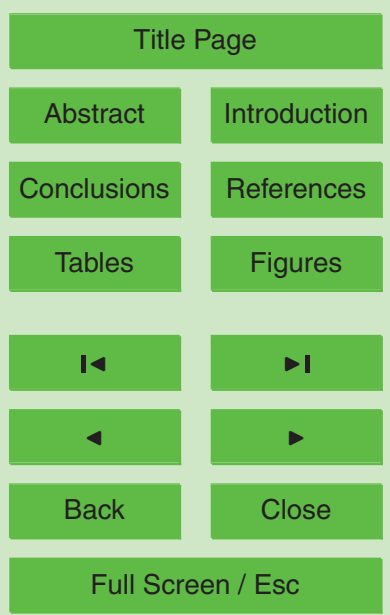

Printer-friendly Version

Interactive Discussion

- no evidence of rupture was noticed (Buishand and Pettit tests); 
- a small positive trend was observed on 2 basins (Aval and Bodo) on runoff coefficient (with a $90 \%$ threshold confidence);

- in all the cases, the segmentation proposed by the Hubert test includes the whole series, indicating that there is no significant segmentation possible time. It shows a clear trend: in the three basins, the volume of discharge per hour increased between period 1 and period 2. It increased significantly in the Aval basin where the runoff coefficient did not increase between the two periods due to the strong increase in infiltration within the sandy creek bed.

\section{Discussion}

When comparing the land cover maps of 1993 and 2007 (Fig. 2; see also Table 1), we can notice large changes in land cover distribution; this leads to significant changes in surface features and soil hydrodynamic behaviour. These have been determined by Casenave and Valentin (1989) giving for each category a runoff coefficient. In the same basin, Mamadou (2011) and Le Breton (2011) observed the following runoff coefficients (Table 7$)$ at the plots scale $\left(10\right.$ and $\left.100 \mathrm{~m}^{2}\right)$.

It was noticed that there is no change in rainfall annual amount (Table 6) during the two observation periods (1991-1994 and 2004-2010); moreover, it was previously shown that the mean rainfall intensity did not change significantly in last decades (Amogu et al., 2010). Le Barbé et al. (2002) demonstrated that the West African drought begun in 1968 was characterised by a decrease in the annual number of rainfall events, without any change in the intensity or the total amount distributions of the events.

However, the rise in runoff coefficient observed between both observation periods was due to some events where runoff coefficients were equal or higher than $100 \%$ : 5 in the Bodo catchments and 2 in the Aval catchments; this was observed only two

HESSD

$8,1569-1607,2011$

\section{Runoff evolution according to land use change}

L. Descroix et al.

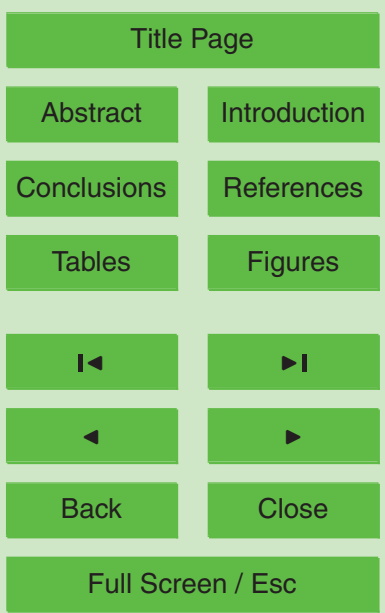

Printer-friendly Version

Interactive Discussion 
times in both basins in the first observation period. This was caused by an increase in the area of catchments, and this explains why the catchment where land use evolved less is the one where increase in runoff is the highest. This evolved sufficiently to provoke a change in connectivity. In some cases (major rainy events), the catchments 5 connectivity is modified in the tiger bush plateau and additional bare soil areas were, for these events, connected to the studied basin. In certain cases, an overflowing of a bare soil strip can provoke a lateral bypassing of a vegetated strip causing a temporary (for some minutes) extension of the catchment area of the gully. But the appearance or increase in this kind of connection is commonly linked to the land use 10 changes, particularly the shortening of a vegetated strip by wood cutters, leading to modifications in the catchment's water collecting areas, and to an apparent increase in runoff coefficient, exceeding $100 \%$ in extreme cases.

Neutron counting regularly processed in the vegetated strip of Tiger Bush, gullies and spreading areas showed a high annual soil moisture variability up to a depth of $1510 \mathrm{~m}$, while all the other parts (millet, fallow, degraded areas), had slight changes only up to a depth of $2 \mathrm{~m}$ (Table 4 and Fig. 4).

Figure 2 and Table 1 show a strong increase in the area of degraded crops and fallows, characterised by "degraded soils". As these soils are crusted and have a low infiltration capacity, these land use changes could explain the increase in runoff coefficient at the small basin scale. The fact that the runoff coefficient of the Aval basin did not increase as expected considering Table 7 and Fig. 2 is due to another consequence of land degradation: the deposit of significant volumes of sand at the bottom of gullies favouring infiltration over runoff. In the Wankama basin, (14 km north of Tondi Kiboro), Descroix et al. (2011) showed that in a $150 \mathrm{~m}$ long section of the creek, $20000 \mathrm{~m}^{3}$ of 25 water infiltrated each year in the creek bed, and this constituted $53 \%$ of the volume discharged at the upstream edge of the considered reach. In the same neighbouring basin, Le Breton (2011) showed that there was a great extension of gully networks between 1950 and 2004. This was also observed in Northern Burkina by Karambiri et al. (2003). Peugeot et al. (1997) showed that there was no infiltration under the Tondi
HESSD

8, 1569-1607, 2011

\section{Runoff evolution \\ according to land use change}

L. Descroix et al.

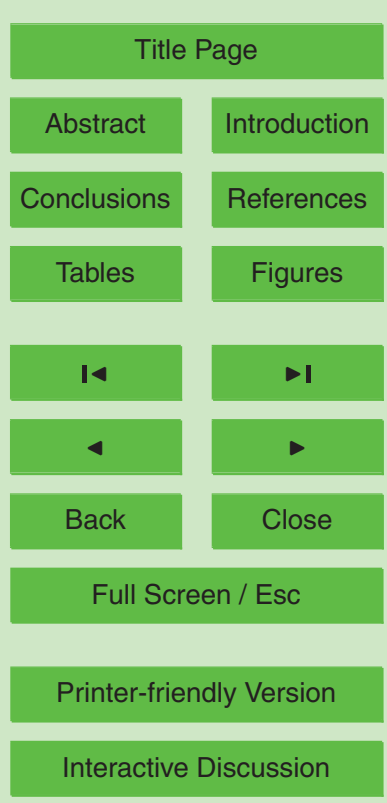


Kiboro basin, talking about the fields and degraded areas; but they envisaged the role of gullies in infiltrating significant volumes of water. In this same basin, Esteves and Lapetite (2003) noticed that between 1991 and 1994, "infiltration through the bottom of the gully between two gauging stations led to considerable runoff water transmis5 sion losses". Gullies and sandy deposits as spreading areas have been determined as likely areas of deep infiltration and water table recharge (Leblanc et al., 2008; Favreau et al., 2009; Descroix et al., 2011). Downstream of the Aval and Bodo basins a small pond collects the streams from these basins; as there is no outlet from this pond, and it dries up some hours after the rainfall event, it could be considered that most 10 of stream water measured at Aval and Bodo stations infiltrates under this pond: more than $10000 \mathrm{~m}^{3} \mathrm{yr}^{-1}$ on average from each of the two gullies, more than $13000 \mathrm{~m}^{3} \mathrm{yr}^{-1}$ in the Aval catchment, and more than $28000 \mathrm{~m}^{3} \mathrm{yr}^{-1}$ in the Bodo catchment (Table 8). These values are almost identical to those measured in the Wankama basin (Descroix et al., 2011).

15 These areas could be responsible for part of the acceleration in the water table recharge noticed in this region in the last 20 years (Leduc et al., 2001; Leblanc et al., 2008). The increasing contribution of deep infiltration under the gullies and spreading areas should explain the increasing rise in water table levels in these basins (Séguis et al., 2004; Massuel et al., 2006; Favreau et al., 2009; Descroix et al., 2011).

Such increases in runoff coefficient were observed early in small experimental catchments in Burkina Faso (Albergel, 1987) and in "regional size" catchments such as the Sirba River, tributary of Niger River, (Mahé et al., 2003) or the Nakambé River (Mahé et al., 2005) one of the upper branch of Volta river, and more recently in small tributaries of the Niger River (Amogu, 2009; Amogu et al., 2010).

Values of the $\alpha$ parameter in Antecedent Precipitation Index calculation measured in this study are consistent with the fixed value of 0.5 for the Sahel area (Chevallier, 1983). This matches with values observed in degraded semi-arid areas of Northern Mexico with dominant Horton-type processes in hydrology ( $\alpha$ parameter higher than 0.1 ) (Descroix et al., 2002). The decrease in $H_{\max }$, the maximal soil water content the soil

\section{HESSD}

8, 1569-1607, 2011

\section{Runoff evolution \\ according to land use change}

L. Descroix et al.



Interactive Discussion 
water holding capacity in the basin is supposed to be related with the soil crusting; this trend was observed by Casenave and Valentin (1989) at the local scale, and by Amogu et al. (2010) at the regional scale. The significant accumulation of sand in the gullies in the lowest parts of the catchments, that causes the increase in $P_{\max }$, the maximal 5 rainfall amount which does not produce runoff, has been observed in the Tondi Kiboro catchments during the two periods (Esteves and Lapetite, 2003; Descroix et al., 2011), by the strong decrease in runoff coefficient between the upstream station (Amont) and the downstream one (Aval), and confirmed by soil moisture monitoring at up to $3 \mathrm{~m}$ soil depth, neutron counting ( $\max 20 \mathrm{~m}$ ), piezometric measurements (the water table, up 10 to $50 \mathrm{~m}$ ); this was also observed in the Wankama catchment, $15 \mathrm{~km}$ northward from Tondi Kiboro (Descroix et al., 2011). $K_{\max }$ (the maximal runoff coefficient) increased sufficiently in the "Bodo" catchment between the two observation periods to compensate the infiltration in the downstream reach of the basin where sandy deposit filled the bottom of the gully. As it has been shown, this is linked to changes in connectivity, causing temporary increase in the catchment area. The sandy accumulation in the valleys was observed by Leblanc et al. (2008); its influence on deep infiltration was suggested by Esteves and Lapetite (2003) and Massuel et al. (2006) and measured by Descroix et al. (2011).

Finally, the duration of stream flow have been decreasing at the Aval and Bodo stations, and this is probably linked to the effect of infiltration below the channel, which significantly diminishes the total volume at the outlet of the catchments.

\section{Conclusions}

Comparing data measured at the beginning of the 1990s (1991-1994) and data collected in the mid-2000s (2004-2010) made it possible to determine a series of modifications that have occurred in the water cycle in small Sahelian basins (from 4 to $12 \mathrm{ha}$ ). The main changes that were observed are the following:
HESSD

8, 1569-1607, 2011

\section{Runoff evolution according to land use change}

L. Descroix et al.




- An increase in discharge and runoff coefficients in small catchments in the Sahel, as has been observed previously at the regional scale;

- This increase is lower or non-existent in the downstream part of the catchments, where simultaneously a strong and deep infiltration is measured under the bed stream in these areas. Each year more than $42000 \mathrm{~m}^{3}$ of water infiltrates under the spreading area shared by the two basins (mean 2004-2010), while this value was $37000 \mathrm{~m}^{3}$ in 1991-1994; gullies and spreading areas have been confirmed as deep infiltration areas by soil moisture monitoring ;

- A decrease in the duration of runoff and floods, from 28 to $18 \mathrm{~h}$ per year for the Aval catchment and from 63 to $26 \mathrm{~h}$ per year in the Bodo catchment; then more water runs in a shortened period of time;

- Modelling the rainfall-runoff relationship showed an increase in runoff coefficients and values of the $\alpha$ parameter (evidence of decrease in soil water content depletion); $H_{\max }$ decreased between the two periods, due to soil crusting, which caused a decrease in soil water holding capacity. Paradoxically, the use of the NAZAS model highlights an increase in $P_{\max }$ (maximal rainfall amount which does not produce runoff) due to the high water volumes infiltrated in newly extended sandy deposit areas (gullies and spreading areas). This can be explained by land use changes, because bare and degraded soils areas increased significantly between period 1 and period 2.

This coupled land use and hydrologic cycle evolution is common in the Sahel, and the increase in runoff, particularly, is observed at all the spatial scales. This work describes the processes at the elementary (some hectares) catchment scale.

The Aval basin was treated with anti-erosive devices since 2010; in the coming 25 years, we aim to compare the evolution of runoff in the equipped and non-equipped catchments.

HESSD

$8,1569-1607,2011$

\section{Runoff evolution according to land use change}

L. Descroix et al.

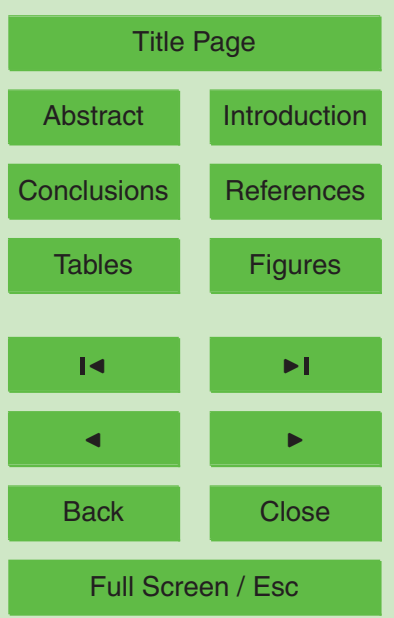

Printer-friendly Version

Interactive Discussion 


\section{Appendix A}

The Nazasm model (in Descroix et al., 2002a, Journal of Hydrology, 263, 114-130

5 (i) The following rainfall-runoff relation is assumed to hold for any rainy event, $n$ :

$\sqrt{R} d_{\mathrm{n}}=K_{\mathrm{n}}\left(P_{\mathrm{n}}-P_{0 \mathrm{n}}\right)$ with $P_{\mathrm{n}}>P_{0 \mathrm{n}}$

where $R d_{\mathrm{n}}$ and $P_{\mathrm{n}}$ are the runoff depth and the rainfall amount respectively, both expressed in $\mathrm{mm}$. $K_{\mathrm{n}}$ (in $\mathrm{mm}^{-1 / 2}$ ) is a parameter depending on the soil surface hydraulic conductivity, on the catchment area and on the proportion of the catchment contributing to runoff. $P_{0 \mathrm{n}}(\mathrm{mm})$ is the rainfall below which there is no runoff.

Because it has been observed that all the measured values of $\sqrt{R d_{\mathrm{n}}}$ and $P_{\mathrm{n}}$ were included between two straight lines, $K_{\mathrm{n}}$ can be expressed as:

$K_{\mathrm{n}}=K_{\min }+\left[\left(K_{\max }-K_{\min }\right) /\left(P_{0 \max }-P_{0 \min }\right)\right] \cdot\left(P_{0 \max }-P_{0 \mathrm{n}}\right)$

Where $K_{\max }, K_{\min }, P_{0 \max }$ and $P_{0 \min }$ correspond to the maximum and minimum values, respectively, of $K$ and $P_{0 n}$ for either the plots or the catchments.

(ii) By assimilating the soil to a reservoir, $P_{0 n}$ can be expressed as :

$P_{0 \mathrm{n}}=C\left(H_{\max }-\mathrm{API}_{\mathrm{n}}\right)$ with $\mathrm{API}_{\mathrm{n}} \leq H_{\max }$

where $C$ is a parameter taking into account most likely rainfall intensity and indirectly the catchment heterogeneity, the water storage of the soil surface (including vegetation

and litter) and the mechanical effect of raindrops on the soil. $H_{\max }$ is the maximum water storage of the reservoir $(\mathrm{mm})$ and $\mathrm{API}_{\mathrm{n}}(\mathrm{mm})$ is its actual level at a given time.

(iii) Following the definition of the Antecedent Precipitation Index (Kohler and Linsley, 1951, Chevallier, 1983), $\mathrm{API}_{\mathrm{n}}$ is calculated as :

$\mathrm{API}_{\mathrm{n}}=\left(\mathrm{API}_{\mathrm{n}-1}+P_{\mathrm{n}-1}\right) \exp (-\alpha \Delta t)$

\section{Runoff evolution according to land use change}

L. Descroix et al.



Printer-friendly Version

Interactive Discussion 
where $\Delta \mathrm{t}=t_{\mathrm{n}}-t_{\mathrm{n}-1}$ is the time (day and/or fraction of day) elapsed between the end of the previous rain event $P_{\mathrm{n}-1}$ and the beginning of the current one $\left(P_{\mathrm{n}}\right)$.

The parameter $\alpha\left(\right.$ day $\left.^{-1}\right)$ is the inverse of the characteristic time of soil moisture depletion.

$5 \quad$ Introducing Eq. (4) into Eq. (3) and then into Eq. (1), gives:

$$
\sqrt{R d_{\mathrm{n}}=K_{\mathrm{n}}\left\{P_{n}-C\left[H_{\max }-\left(\mathrm{API}_{\mathrm{n}-1}+P_{\mathrm{n}-1}\right) \exp \left(-\alpha\left(t_{\mathrm{n}}-t_{\mathrm{n}-1}\right)\right)\right]\right\}}
$$

The model (Eq. 5) has seven parameters $\left(C, H_{\max }, \alpha, K_{\max }, K_{\min }, P_{0 \max }, P_{0 \min }\right)$ to be determined. This was achieved by splitting the time series of observed $\left(P_{\mathrm{n}}, R d_{\mathrm{n}}\right)$ values in two parts (one event out of two): one half being used for the calibration of the parameters by best fitting between calculated and measured values of runoff depths, and the other one for the validation, the values of the parameters being kept unchanged.

The model is initialised at the beginning of the rainy season where $A P I_{0}$ is assumed to be zero.

15 Acknowledgements. This study was partially funded by the ANR ECLIS (Contribution of livestock to the reduction of rural population vulnerability and to the promotion of their adaptability to climate and society changes in Sub-Saharan Africa ) French program. It was carried out within the framework of the AMMA project (African Monsoon Multidisciplinary Analyses). Based on a French initiative, AMMA was built by an international scientific group and

20 is currently funded by a large number of agencies based in France, the United Kingdom, the United States of America, and Africa. It has been the beneficiary of a major financial contribution from the European Community's Sixth Framework Research Program. Detailed information on scientific coordination and funding is available on the AMMA International web site http://www.amma-international.org. This research is also funded by the ECCO-PNRH French

National Hydrological Research Program. Many thanks to Phoebe Peterman (Niamey) who marked this submitted paper.

\section{HESSD}

$8,1569-1607,2011$

\section{Runoff evolution according to land use change}

L. Descroix et al.

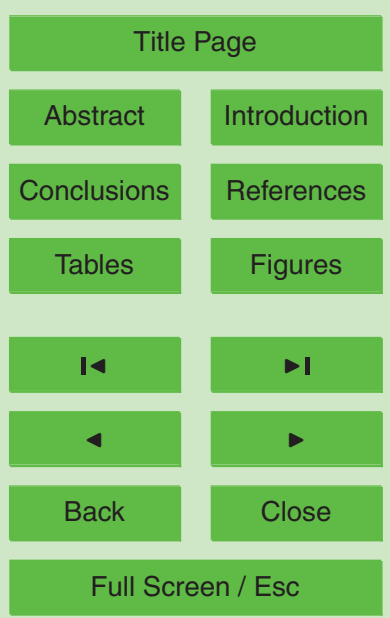

Printer-friendly Version

Interactive Discussion 
The publication of this article is financed by CNRS-INSU.

\section{References}

Ada, L. and Rockstrom, J. : Diagnostic sur le système agraire du "Zarmaganda central" (Niger), Mémoire de fin d'études INAPG, Paris, 82 p., 1993.

Albergel, J.: Genèse et prédétermination des crues au Burkina Faso; $\mathrm{du}^{2}$ au $\mathrm{km}^{2}$, étude des paramètres hydrologiques et de leur évolution. PhD thesis, Université Paris 6, Editions de l'Orstom, 330 p., 1987.

Amani, A. and Nguetora, M.: Evidence d'une modification du régime hydrologique du fleuve 10 Niger à Niamey, in: FRIEND 2002 regional Hydrology: bridging the gap between research and practice, edited by: Van Lannen, H. and Demuth, S., Proc. of Friend Conf. Cape Town, S.A., IAHS Pub., 274, 449-456, 2002.

Amogu, O.: La dégradation des espaces sahéliens et ses conséquences sur l'alluvionnement du fleuve Niger: méthodes expérimentales et modélisation", PhD Thesis, Université Joseph

15 Fourier, Grenoble,448 p., 2009.

Amogu O., Descroix, L., Yéro, K. S., Le Breton, E., Mamadou, I., Ali, A., Vischel, T., Bader, J.-C., Moussa, I. B., Gautier, E., Boubkraoui, S., and Belleudy, P.: Increasing River Flows in the Sahel?, Water, 2(2), 170-199, 2010.

Anyamba, A. and Tucker, C. J.: Analysis of Sahelian vegetation dynamics using NOAA-AVHRR $20 \quad$ NDVI data from 1981-2003, J. Arid Environ., 63(3), 596-614, 2005.

Cappus, P.: Etude des lois de l'écoulement. Application au calcul et à la prévision des débits, Bassin expérimental d'Alrance. La Houille Blanche, No. A, Grenoble, France, 521-529, 1960.

Casenave, A. and Valentin, C.: Les états de surface de la zone sahélienne. Influence sur l'infiltration. Col. Didactique. Editions Orstom, Paris, 229 p., 1989.

\section{Runoff evolution according to land use change}

L. Descroix et al.

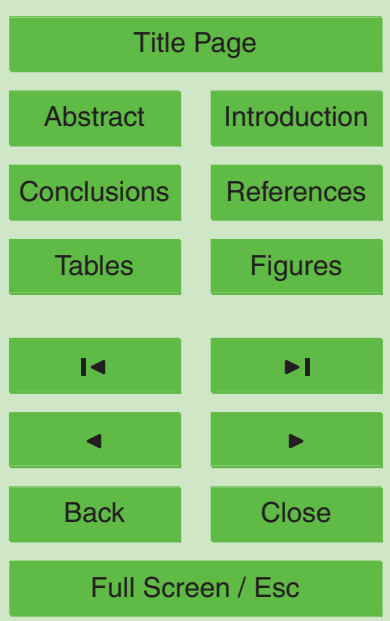

Printer-friendly Version

Interactive Discussion 
Chevalier, P. : L'indice des précipitations antérieures. Cah. Orstom, sér. Hydrologie, vol. XX, $\mathrm{n}^{\circ}$ 3-4: 179-189, 1983.

Chinen, T.: Recent accelerated gully erosion and its effects in dry savanna, southwest of Niger, in: Human response to drastic changes of environments in Africa. Faculty of Economics,

$5 \quad$ Ryutsu Keizai University 120, Hirahata, Ryugasaki 301-8555, Japan, 67-102, 1999.

CRESA: Impacts des investissements dans la gestion des ressources naturelles (GRN) au Niger: rapport de synthèse, 65 pp., Niamey, 2006.

Demont, M. and Jouve, P.: Evolution d'agro-systèmes villageois dans la region de Korhogo (ord Côte d'Ivoire): Boserup vs Malthus, opposition ou complémentarité?, Dynamiques agraires et construction sociale du territoire. Séminaire CNEARC-UTM, Montpellier, France, 93-108, 1999.

Descroix, L., Nouvelot, J. F., and Vauclin, M.: Evaluation of an antecedent precipitation index to model runoff in the western Sierra Madre (North-west Mexico), J. Hydrol., 263, 114-130, 2002.

Descroix, L., Viramontes, D., Estrada, J., Gonzalez Barrios, J.-L., and Asseline, J-P.: Investigating the spatial and temporal boundaries of Hortonian and Hewlettian runoff in Northern Mexico, J. Hydrol., 346, 144-158, 2007.

Descroix, L., Gonzalez Barrios, J. L., Viramontes, D., Poulenard, J., Anaya, E., Esteves, M., and Estrada, J.: Gully and sheet erosion on subtropical mountainous slopes: Their respective roles and the scale effect, Catena, 72, 325-339, 2008.

Descroix, L., Mahé, G., Lebel, T., G., Favreau, G., Galle, S., Gautier, E., Olivry, J-C., Albergel, J., Amogu, O., Cappelaere, B., Dessouassi, R., Diedhiou, A., Le Breton, E., Mamadou, I., and Sighomnou, D.: Spatio-Temporal Variability of Hydrological Regimes Around the Boundaries between Sahelian and Sudanian Areas of West Africa: A Synthesis, J. Hydrol., AMMA special issue., 375, 90-102, 2009.

Descroix, L., Laurent, J-P., Boubkraoui, S., Ibrahim, B., Cappelaere, B., Favreau, G., Mamadou, I., Le Breton, E., Quantin, G., and Boulain, N.: Experimental evidence of deep infiltration under flat sandy areas, J. Hydrol., submitted, 2011.

Di Vecchia, A., Genesio, L., Pini, G., Sorani, F., and Tarchiani, V.: Monitoring drylands ecosystems dynamics for sustainable development policies: The Keita experience, International Scientific Conference on Desertification and Drylands Research Commemorating 50 Years of Drylands Research Tunis. 19 Tunisia-21 June 2006, 2006.

Esteves. $M$ and Lapetite, J. M.: A multi-scale approach of runoff generation processes in a

HESSD

$8,1569-1607,2011$

\section{Runoff evolution \\ according to land use change}

L. Descroix et al.

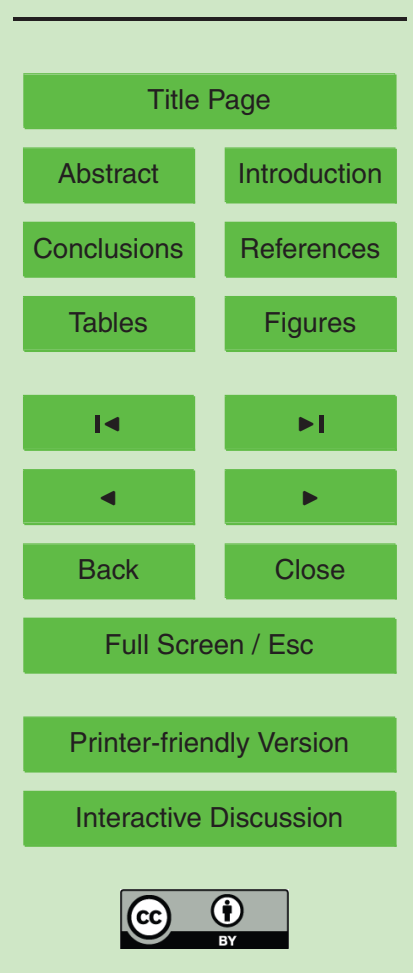


sahelian gully catchment: a case study in Niger, Catena 50, 255-271, 2003.

Favreau, G., Cappelaere, B., Massuel, S., Leblanc, M., Boucher, M., Boulain, N . and Leduc, C.: Land clearing, climate variability, and water resources increase in semiarid southwest Niger: a review, Water Resour. Res., 45, W00A16, doi:10.1029/2007WR006785, 2009.

5 Govaerts, Y. and Lattanzio, A.: Estimation of surface albedo increase during the eighties Sahel drought from Meteosat observations, Glob. Planet. Change, 64, 139-145, 2008.

Hardin, G.: The Tragedy of the Commons, Science, (162)3859, 1243-1248, 1968.

Hewlett, J. D.: Soil moisture as a source of base flow from steep mountain watershed. US forest Service, Southeastern Forest Experiment Station, Asheville, North Carolina, 1961.

Hein, L. and De Ritter, N.: Desertification in the Sahel: a reinterpretation, Glob. Change Biol., 12, 751-758, 2006.

Hiernaux, P., Ayantunde, A., Kalilou, A., Mougin, A., Gérard, B., Baup, F., Grippa, M., and Djaby, B.: Trends in productivity of crops, fallow and rangelands in Southwest Niger: impact of land use, management and variable rainfalls, J. Hydrol., AMMA special issue, 375, 65-77, 2009.

Horton, R. E.: The role of infiltration in the hydrologic cycle. EOS. American Geophysical Union Transactions, 14, 44-460, 1933.

Hountondji, Y.-C., Ozer, P., and Nicolas, J.; Mise en évidence des zones touchées par la désertification par télédétection à basse résolution au Niger, Cybergéo: revue euroépenne de géographie, $n^{\circ}$ 291, 2004.

IRD: Khronostat, logiciel statistique de series chronologiques. Copyright Orstom 1998-IRD 2002, Montpellier, France, 2002.

Karambiri, H., Ribolzi, O., Delhoume, J. P., Ducloux, J., Coudrain-Ribstein, A., and Casenave, A.: Importance of soil surface characteristics on water erosion in a small grazed Sahelian catchment, Hydrol. Process., 17, 1495-1507, 2003.

Kendall, S. M. and Stuart, A.: The advanced theory of statistics. Charles Griffin Londres., 3rd volume, 585 p., in the edition of 1977, 1943.

Larwanou, M., Abdoulaye, M., and Reij, C.: Etude de la régénération naturelle assistée dans la région de Zinder (Niger). Ed. International Resources Group, Washington DC, The USA., p. 48, 2006.

Le Barbé, L., Lebel, T., and Tapsoba, D.: Rainfall variability in West Africa: a hydrological perspective, J. Clim., 15(2), 187-202, 2002.

Leblanc, M., Favreau, G., Massuel, S., Tweed, S., Loireau, M., and Cappelaere, B.: Land
HESSD

8, 1569-1607, 2011

\section{Runoff evolution \\ according to land use change}

L. Descroix et al.

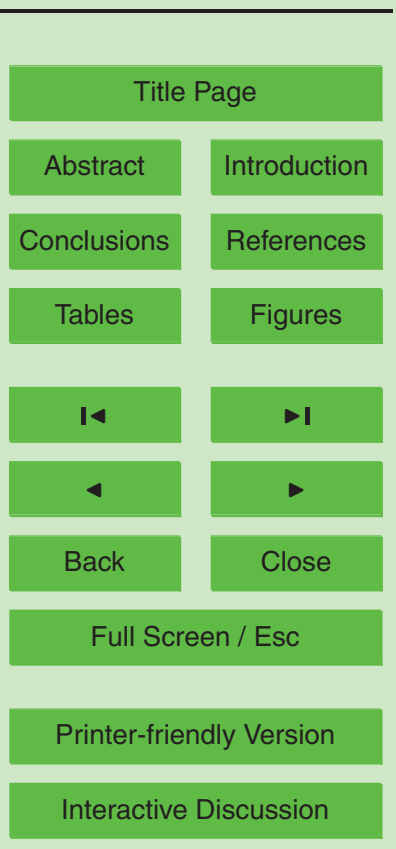


clearance and hydrological change in the Sahel: SW Niger, Glob. Planet. Change, 61(1-2), 49-62, 2008.

Le Breton, E.: Réponse des systèmes hydrologiques et érosifs aux changements environnementaux dans le bassin du Niger moyen Degré carré de Niamey - Niger. PhD, 150 p., 5 université Paris 8, 2011.

Leduc, C., Favreau, G., and Shroeter, P.: Long term rise in a Sahelian water-table: the Continental Terminal in South-West Niger, J. of Hydrol., 243, 43-54, 2001.

Loireau, M.: Espaces, ressources, usages: spatialisation des interactions dynamiques entre les systèmes écologiques au Sahel nigérien. PhD Thesis of Geography, Université Montpel$10 \quad$ lier 3, 410 p., 1998.

Mahé, G., Leduc, C., Amani, A., Paturel, J.-E., Girard, S., Servat, E., Dezetter, A.: Augmentation récente du ruissellement de surface en région soudano sahélienne et impact sur les ressources en eau. In: Hydrology of the mediterranean and semi-arid regions. Proc. of the Intl Conf, Montpellier. IAHS Publication n² 278, 215-222, 2003.

15 Mahé G., Paturel J. E., Servat E., Conway D., and Dezetter A.: Impact of land use change on soil water holding capacity and river modelling of the Nakambe River in Burkina-Faso, J. Hydrol., 300, 33-43, 2005.

Mamadou, I.: La dynamique accélérée des koris de la région de Niamey: conséquence sur l'ensablement du fleuve Niger. PhD thesis, Université Paris 8., 250 p., 2011.

20 Massuel, S., Favreau, G., Descloitres, M., Le Troquer, Y., Albouy, Y., and Cappelaere, B.: Deep infiltration through a sandy alluvial fan in semiarid Niger inferred from electrical conductivity survey, vadose zone chemistry and hydrological modelling, Catena, 67, 105-118, 2006.

Nouvelot, J. F.: Guide des pratiques hydrologiques sur les petits bassins versants ruraux en Afrique tropicale et équatoriale. Paris, Ed. ORSTOM-CIEH, 534 p., 1993.

Peugeot, C., Esteves, M., Galle, S., Rajot, J.-L., and Vandervaere, J-P.: Runoff generation processes: results and analysis of field data collected at the East Central Supersite of the HAPEX-Sahel experiment, J. Hydrol., 188-189, 179-202, 1997.

Rasmussen, K., Bjarne, F., and Madsen, J-E.: Desertification in reverse ? Observations from northern Burkina Faso, Global Environmental Change, 11, 271-282, 2001.

30 Reij., C., Tappan, G., and Belemvire, A.: Changing alnd management practices and vegetation on the Central Plateau of Burkina Faso (1968-2002), J. Arid Environ., 63, 642-659, 2005

Reij, C., Tappan, G., and Smale, M.: Agroenvironmental transformation in the Sahel, another kind of "green revolution". IFPRI discussion paper 00914, 2020 vision initiative, 43 p., 2009.

HESSD

8, 1569-1607, 2011

\section{Runoff evolution \\ according to land use change}

L. Descroix et al.

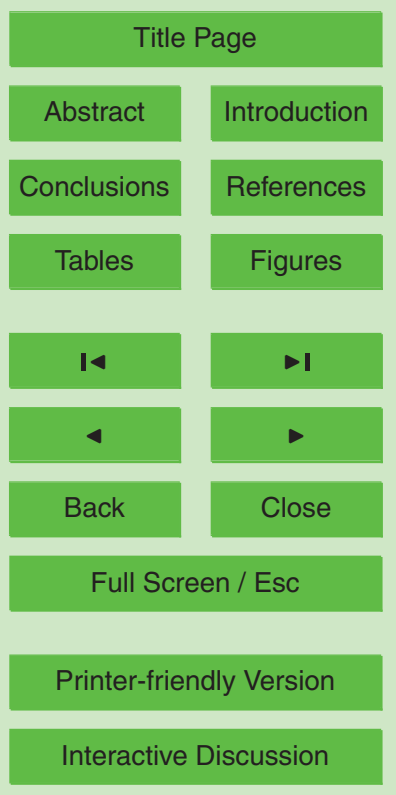


Séguis, L., Cappelaere, B., Milési, G., Peugeot, C., Massuel, S., and Favreau, G.: Simulated impacts of climate change and land-clearing on runoff from a small Sahelian catchment, Hydrol. Process., 18, 3401-3413, 2004.

Tiffen, M., Mortimore, M., and Gichuki, F.: More people, less erosion: Environmental recovery in Kenya. John Wiley and Sons, London, 311 p., 1994.

Vandervaere, J.-P., Peugeot, C., Vauclin, M., Angulo Jaramillo, R., and Lebel, T.: Estimating hydraulic conductivity of crusted soils using disc infiltrometers and minitensiometers, J. Hydrol., 188-189, 203-223, 1997.

World Meteorological Organization: Climatic change, by a working group of the Commission for Climatology. World Meteorological Organization, WMO 195, TP 100, Tech. Note $n^{\circ} 79,78$ p., 1966.

\section{HESSD}

8, 1569-1607, 2011

\section{Runoff evolution according to land use change}

L. Descroix et al.

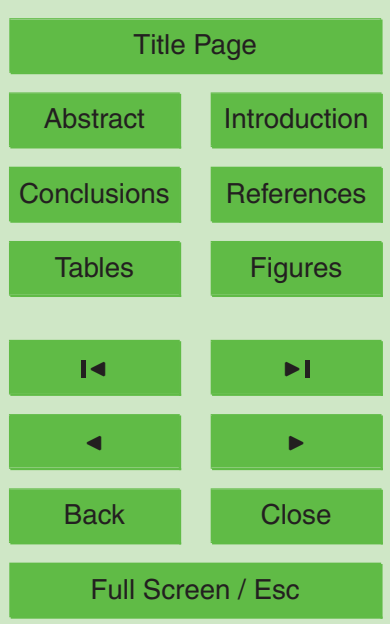

Printer-friendly Version

Interactive Discussion 


\section{HESSD}

$8,1569-1607,2011$

\section{Runoff evolution according to land use change}

Table 1. The land cover in each catchment in 1993 and in 2007.

\begin{tabular}{lrrrrrrr}
\hline & \multicolumn{2}{c}{ BODO 12.1 ha } & \multicolumn{2}{c}{ AMONT 4.6 ha } & \multicolumn{2}{c}{ AVAL 6.7 ha } \\
\hline hectares & $\%$ & hectares & $\%$ & hectares & $\%$ \\
\hline tiger bush (vegetated strip) & 1.40 & 11.57 & 1.10 & 22.31 & 0.00 & 0.00 \\
bare soil in tiger bush & 3.91 & 32.31 & 1.39 & 28.19 & 0.20 & 3.27 \\
Gullies (including sandy deposit) & 1.47 & 12.15 & 0.09 & 1.83 & 0.32 & 5.23 \\
vegetated plateau edge & 0.48 & 3.97 & 1.38 & 27.99 & 0.76 & 12.42 \\
degraded crops and fallow (crusted soils) & 2.72 & 22.48 & 0.97 & 19.68 & 1.46 & 23.86 \\
Crops and fallow & 2.12 & 17.52 & 0.00 & 0.00 & 3.38 & 55.23 \\
\hline 2007 & hectares & $\%$ & hectares & $\%$ & hectares & $\%$ \\
\hline tiger bush (vegetated strip) & 1.65 & 13.64 & 1.00 & 20.28 & 0.00 & 0.00 \\
bare soil in tiger bush & 2.46 & 20.33 & 1.62 & 32.86 & 0.20 & 3.27 \\
Gullies (including sandy deposit) & 1.68 & 13.88 & 0.13 & 2.64 & 0.31 & 5.07 \\
vegetated plateau edge & 0.48 & 3.97 & 1.13 & 22.92 & 0.77 & 12.58 \\
degraded crops and fallow (crusted soils) & 4.03 & 33.31 & 1.05 & 21.30 & 3.88 & 63.40 \\
Crops and fallow & 1.8 & 14.88 & 0.00 & 0.00 & 0.96 & 15.69 \\
\hline
\end{tabular}

L. Descroix et al.






\section{HESSD}

$8,1569-1607,2011$

Table 2. Rainfall, runoff and runoff coefficients for the three basins and for periods 1 and 2.

\begin{tabular}{|c|c|c|c|c|c|c|}
\hline \multicolumn{7}{|c|}{ 1991-1994 } \\
\hline amont & Rain $(\mathrm{mm})$ & Runoff (mm) & $\mathrm{RC}$ & rainfall/runoff & $r^{2} R=\mathrm{a} P+b$ & $r^{2} R=\mathrm{a} P^{2}+b$ \\
\hline 1991 & 440.50 & 178.21 & 0.40 & $R=0.65 P-3.3$ & 0.87 & 0.85 \\
\hline 1992 & 425.50 & 100.50 & 0.24 & $R=0.36 P-1.49$ & 0.86 & 0.82 \\
\hline 1993 & 459.50 & 139.88 & 0.30 & $R=0.43 P-1.97$ & 0.82 & 0.9 \\
\hline 1994 & 653.26 & 300.60 & 0.46 & $R=0.67 P-2.59$ & 0.9 & 0.93 \\
\hline TOTAL 1991-1994 & 1997.76 & 719.20 & & & & \\
\hline Mean 4 years & 512.75 & 180.33 & 0.36 & $R=0.56 P-2.61$ & 0.82 & 0.88 \\
\hline $\begin{array}{c}\text { aval } \\
1991\end{array}$ & Rain & Runoff & $\mathrm{RC}$ & rainfall/runoff & $r^{2} R=a P+b$ & $r^{2} R=\mathrm{a} P^{2}+b$ \\
\hline 1992 & 425.50 & 73.52 & 0.17 & $R=0.33 P-2.27$ & 0.74 & 0.66 \\
\hline 1993 & 452.00 & 108.78 & 0.24 & $R=0.37 P-1.64$ & 0.81 & 0.86 \\
\hline 1994 & 660.04 & 215.67 & 0.33 & $R=0.5 P-2.22$ & 0.86 & 0.90 \\
\hline TOTAL 1992-1994 & 1537.54 & 396.88 & 0.26 & & & \\
\hline Mean 3 years & 512.51 & 132.65 & 0.26 & $R=0.43 P-2.3$ & 0.79 & 0.84 \\
\hline bodo & Rain & Runoff & $\mathrm{RC}$ & rainfall/runoff & $r^{2} R=a P+b$ & $r^{2} R=a P^{2}+b$ \\
\hline 1991 & 492.00 & 262.00 & 0.53 & $R=0.65 P-1.7$ & 0.67 & 0.69 \\
\hline 1992 & 417.00 & 127.00 & 0.30 & $R=0.39 P-1.1$ & 0.69 & 0.70 \\
\hline 1993 & 475.00 & 103.00 & 0.22 & $R=0.41 P-2.6$ & 0.80 & 0.73 \\
\hline 1994 & 555.00 & 249.00 & 0.45 & $R=0.59 P-2.6$ & 0.75 & 0.87 \\
\hline TOTAL 1991-1994 & 1939.00 & 741.00 & 0.38 & & & \\
\hline Mean 4 years & 484.75 & 185.25 & 0.38 & $R=0.53 P-2.14$ & 0.68 & 0.78 \\
\hline
\end{tabular}

\section{Runoff evolution according to land use change}

L. Descroix et al.

Title Page

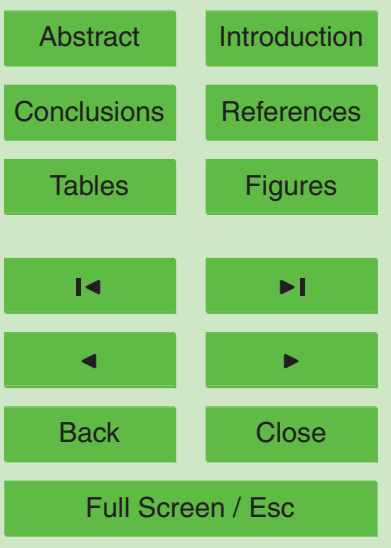

Printer-friendly Version

Interactive Discussion 
Table 2. Continued.

\begin{tabular}{|c|c|c|c|c|c|c|}
\hline \multicolumn{7}{|c|}{ 2004-2010 } \\
\hline amont & Rain (mm) & Runoff (mm) & $\mathrm{RC}$ & rainfall/runoff & $r^{2} R=a P+b$ & $r^{2} R=\mathrm{a} P^{2}+b$ \\
\hline 2004 & 533 & 251.30 & 0.47 & $R=0.64 P-2,9$ & 0.83 & 0.80 \\
\hline 2005 & 400 & 94.79 & 0.24 & $R=0.56 P-3.4$ & 0.86 & 0.80 \\
\hline 2006 & 561 & 229.80 & 0.41 & $R=0.78 P-5.4$ & 0.81 & 0.78 \\
\hline 2007 & 524 & 288.38 & 0.55 & $R=0.76 P-3.95$ & 0.79 & 0.72 \\
\hline 2008 & 611 & 333.84 & 0.55 & $R=0.83 P-5.4$ & 0.94 & 0.91 \\
\hline 2009 & 437 & 189.40 & 0.43 & $R=0.83 P-5.4$ & 0.80 & 0.84 \\
\hline 2010 & 428 & 133.60 & 0.30 & $R=0.45 P-1.72$ & 0.85 & 0.92 \\
\hline TOTAL 2004-2010 & 3493 & 1521 & 0.43 & & & \\
\hline Mean 7 years & 499 & 217 & 0.43 & $R=0.73 P-4.5$ & 0.84 & 0.83 \\
\hline aval & Rain (mm) & Runoff (mm) & $\mathrm{RC}$ & rainfall/runoff & $r^{2} R=\mathrm{a} P+b$ & $r^{2} R=\mathrm{a} P^{2}+b$ \\
\hline 2004 & 533 & 171 & 0.32 & $R=0.63 P-3.2$ & 0.72 & 0.84 \\
\hline 2005 & 400 & 65 & 0.16 & $R=0,31 P-1.7$ & 0.80 & 0.74 \\
\hline 2006 & 561 & 132 & 0.24 & $R=0.51 P-4.3$ & 0.80 & 0.77 \\
\hline 2007 & 524 & 127 & 0.24 & $R=0.46 P-4.06$ & 0.82 & 0.78 \\
\hline 2008 & 611 & 193 & 0.32 & $R=0.52 P-3.8$ & 0.89 & 0.89 \\
\hline 2009 & 461 & 103 & 0.22 & $R=0.41 P-2.6$ & 0.74 & 0.71 \\
\hline 2010 & 424 & 79 & 0.19 & $R=0.27 P-1.04$ & 0.86 & 0.92 \\
\hline TOTAL 2004-2010 & 3513 & 870 & 0.26 & & & \\
\hline Mean 7 years & 502 & 171 & 0.26 & $R=0.46 P-3.1$ & 0.77 & 0.79 \\
\hline bodo & Rain (mm) & Runoff (mm) & $\mathrm{RC}$ & rainfall/runoff & $r^{2} R=a P+b$ & $r^{2} R=a \mathrm{P}^{2}+b$ \\
\hline 2007 & 523 & 154 & 0.30 & $R=0.53 P-4.5$ & 0.89 & 0.78 \\
\hline 2008 & 611 & 377 & 0.62 & $R=1 P-7.32$ & 0.88 & 0.86 \\
\hline 2009 & 425 & 195 & 0.46 & $R=1 P-7.5$ & 0.84 & 0.84 \\
\hline 2010 & 416 & 207 & 0.50 & $R=0.72 P-2.63$ & 0.90 & 0.93 \\
\hline TOTAL 2007-2010 & 1975 & 933 & 0.47 & & & \\
\hline Mean 4 years & 494 & 233 & 0.47 & $R=0.87 P-7$ & 0.81 & 0.82 \\
\hline
\end{tabular}

\section{HESSD}

8, 1569-1607, 2011

\section{Runoff evolution according to land use change}

L. Descroix et al.

\section{Title Page}

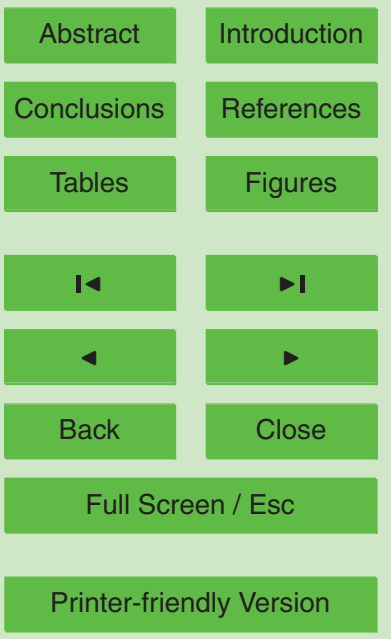

Interactive Discussion 


\section{HESSD}

8, 1569-1607, 2011

\section{Runoff evolution according to land use change}

L. Descroix et al.

Table 3. Total duration of stream flow in hours per year.

\begin{tabular}{|c|c|c|c|c|c|c|c|c|c|c|c|c|c|}
\hline $\begin{array}{l}\text { hours/ } \\
\text { year }\end{array}$ & & & & & mean & & & & & & & & mean \\
\hline basin & 1991 & 1992 & 1993 & 1994 & $91-94$ & 2004 & 2005 & 2006 & 2007 & 2008 & 2009 & 2010 & 04-10 \\
\hline AMONT & 20.64 & 28.8 & 36.96 & 53.04 & 34.9 & 31.2 & 17.4 & 36.5 & 50.6 & 46.03 & 23.2 & 12.5 & 34.2 \\
\hline AVAL & & 16.32 & 25.68 & 42.24 & 28.08 & 24.6 & 13 & 20 & 18.6 & 21.8 & 11.3 & 8.13 & 18.2 \\
\hline difference & & 12.48 & 11.28 & 10.8 & 11.52 & 6.6 & 4.4 & 16.5 & 32 & 24.23 & 12 & 4.3 & 16 \\
\hline BODO & 58.7 & 50 & 44 & 98 & 62.67 & & & & 25.0 & 34.0 & 18.7 & 19.4 & 25.9 \\
\hline
\end{tabular}

Title Page

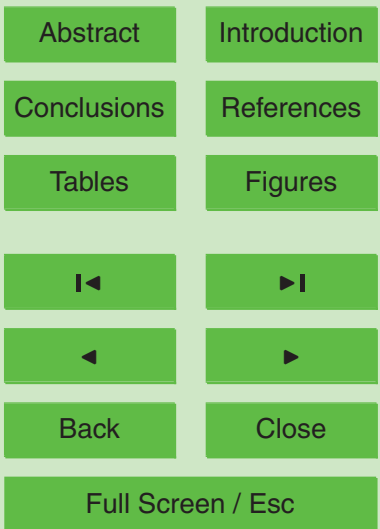

Printer-friendly Version

Interactive Discussion 


\section{HESSD}

$8,1569-1607,2011$

\section{Runoff evolution according to land use change}

Table 4. Mean depth reached by the wetting front per year and per land use ; the date of occurrence of the maximum depth is noticed (the rank of the day from 1 January ).

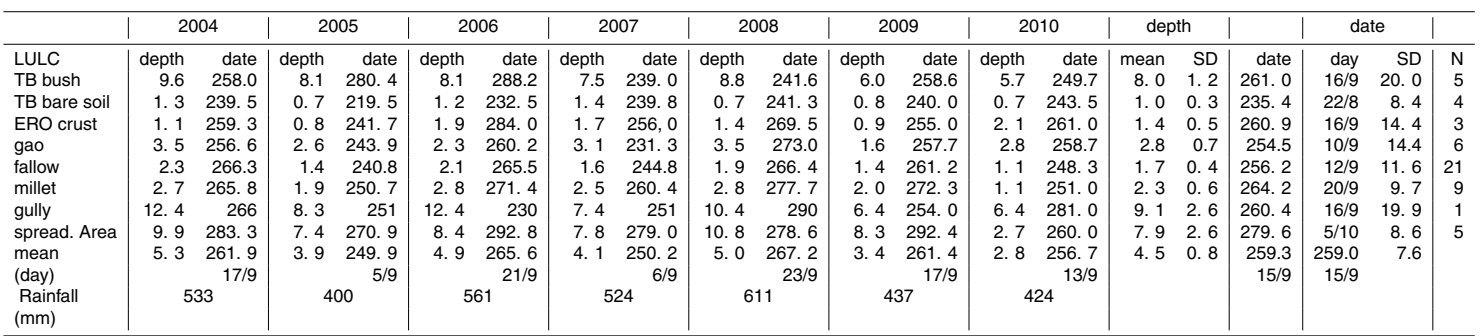

Values in red were partially reconstituted, $N$ is the number of neutron probe measurements site (between 10 and 25 depths documented at each site).

L. Descroix et al.

Title Page

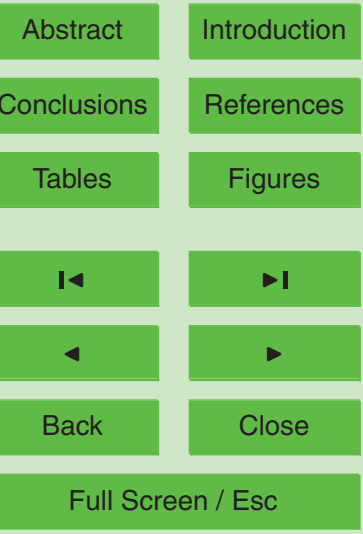

Printer-friendly Version

Interactive Discussion 


\section{HESSD}

8, 1569-1607, 2011

\section{Runoff evolution according to land use change} vation (calibration and validation as well as detailed year per year data are given in appendix).

\begin{tabular}{|c|c|c|c|c|c|c|c|c|}
\hline & $H_{\text {max }}$ & $P_{\max }$ & $K_{\max }$ & $\alpha$ & $r^{2} \mathrm{CRd} / \mathrm{ORd}$ & $r^{2} \mathrm{P} / \mathrm{Rd}$ & $\mathrm{K}$ & Number events \\
\hline \multicolumn{9}{|c|}{ TOTAL of THE TWO PERIODS } \\
\hline TK AMONT & 58 & 30 & 0.83 & 0.39 & 0.88 & 0.98 & 0.64 & 371 \\
\hline TK AVAL & 78 & 24 & 0.75 & 0.60 & 0.85 & 0.97 & 0.56 & 331 \\
\hline TK BODO & 62 & 30 & 0.82 & 0.60 & 0.82 & 0.98 & 0.69 & 251 \\
\hline MOYENNE TOT & 66.3 & 27.8 & 0.80 & 0.52 & 0.85 & 0.97 & 0.65 & \\
\hline \multicolumn{9}{|l|}{ 1991-1994 } \\
\hline AMONT & 68 & 30 & 0.75 & 0.37 & 0.89 & 0.97 & 0.55 & 154 \\
\hline AVAL & 79 & 22 & 0.71 & 0.52 & 0.86 & 0.97 & 0.43 & 109 \\
\hline BODO & 59 & 28 & 0.75 & 0.41 & 0.79 & 0.98 & 0.57 & 125 \\
\hline MOYENNE 91-94 & 68 & 26.7 & 0.74 & 0.43 & 0.85 & 0.97 & 0.52 & \\
\hline \multicolumn{9}{|l|}{ 2004-2010 } \\
\hline AMONT & 52 & 32 & 0.89 & 0.4 & 0.87 & 0.99 & 0.73 & 217 \\
\hline AVAL & 70 & 24 & 0.70 & 0.75 & 0.80 & 0.98 & 0.74 & 222 \\
\hline BODO & 50 & 30 & 0.90 & 0.80 & 0.89 & 0.98 & 0.82 & 126 \\
\hline MOYENNE 04-10 & 57 & 26.7 & 0.83 & 0.65 & 0.86 & 0.98 & 0.76 & \\
\hline
\end{tabular}

$P=$ rainfall amount; $R d=$ runoff depth; $C R d=$ calculated runoff depth; $\mathrm{ORd}=$ observed runoff depth

L. Descroix et al.

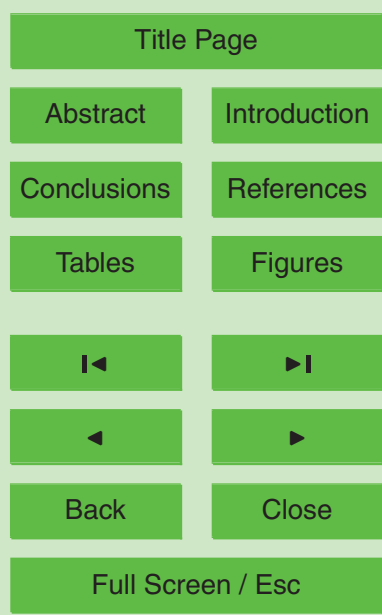

Printer-friendly Version

Interactive Discussion 


\section{HESSD}

$8,1569-1607,2011$

Table 6. Results of trends, persistence and rupture tests in the Northern basin (amont and aval stations).

\begin{tabular}{lcccc}
\hline & Buishand & Pettit & Rank & Hubert \\
\hline RAINFALL & NNN & NNN & NNN & $1991 / 2010$ \\
RC amont & NNN & NNN & NNN & $1991 / 2010$ \\
RC aval & & NNN & NNY & $1992 / 2010$ \\
RC intermediary & & NNN & NNN & $1992 / 2010$ \\
RC bodo & & NNN & NNY & $1991 / 2010$ \\
RD amont & NNN & NNN & NNN & $1991 / 2010$ \\
RD aval & NNN & NNN & NNN & $1992 / 2010$ \\
RD intermediary & NNN & NNN & NNN & $1992 / 2010$ \\
RD bodo & & NNN & NNN & $1992 / 2010$ \\
& & & &
\end{tabular}

\section{Runoff evolution according to land use change}

L. Descroix et al.

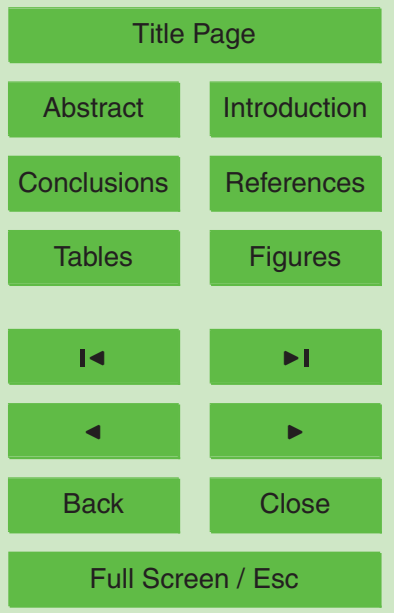

$\mathrm{RC}=$ runoff coefficient; $\mathrm{RD}=$ runoff depth; $\mathrm{TK}$ intermediary = the catchment included between the two stream gauge stations AMONT and AVAL; TK aval is the total catchment.

$N$ in the Buishand and Pettit tests columns means that there is no rupture detected in the series, neither with $99 \%$ nor with $95 \%$ and $90 \%$ of confidence level, and the series have a random character. When there is no letter, the test could not be realised for technical reason (no sufficient sampling generally).

$N$ in the Rank test column means that there is no trend detected in the series (neither with $99 \%$ nor with $95 \%$ and $90 \%$ of confidence level). Y means that a trend is detected, here in two cases with a 90\% confidence level.

The years in Hubert test column mean the segmentation found of the statistical series; this method is based on the trend in the average of the values; here in all the cases, the segment includes the whole series; thus there is no segmentation in the series, suggesting the series are stationary. 


\section{HESSD}

$8,1569-1607,2011$

\section{Runoff evolution according to land use change}

L. Descroix et al.

Table 7. Runoff coefficient observed in plots (average of 4 repetitions per class, and 5 measurement years 2004-2008) (after Le Breton, 2011; Mamadou, 2011).

\begin{tabular}{lrr}
\hline & $\mathrm{Kr} \%$ & erosion $\mathrm{kg} / \mathrm{ha}$ \\
\hline millet & 3.8 & 373 \\
fallow & 10.5 & 881 \\
ERO crust & 60 & 5566 \\
ALG crust & 26 & 863 \\
\hline
\end{tabular}

Title Page

Abstract Introduction

Conclusions References

Tables Figures

14

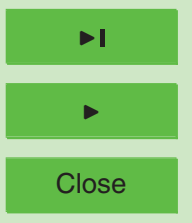

Back

Full Screen / Esc

Printer-friendly Version

Interactive Discussion 


\section{HESSD}

8, 1569-1607, 2011

\section{Runoff evolution according to land use change}

Table 8. Total volume of observed stream flow per basin and per year $\left(\mathrm{m}^{3}\right)$ for periods 1 and 2 .

\begin{tabular}{crrr}
\hline Basin & amont & aval & bodo \\
\hline 1991 & 8340 & & 31892 \\
1992 & 4703 & 8127 & 15472 \\
1993 & 6546 & 11904 & 12565 \\
1994 & 15227 & 23840 & 30370 \\
mean 1991-1994 & 8704 & 14624 & 22575 \\
2004 & 11411 & 21800 & \\
2005 & 4448 & 7014 & \\
2006 & 10461 & 14590 & \\
2007 & 13497 & 14857 & 18807 \\
2008 & 15624 & 21261 & 45875 \\
2009 & 8888 & 11316 & 23799 \\
2010 & 5977 & 8642 & 25179 \\
mean 2004-2010 & 10133 & 13707 & 28415 \\
\hline
\end{tabular}

L. Descroix et al.

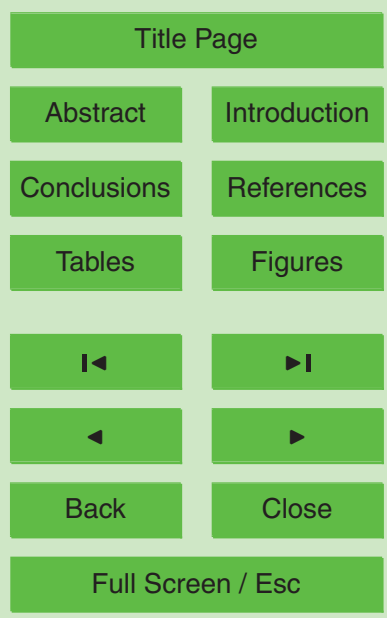

Printer-friendly Version

Interactive Discussion 
Table B. Results of modelling per year including calibration/validation.

\begin{tabular}{|c|c|c|c|c|c|c|c|c|}
\hline & HMAX & PMAX & KMAX & ALPHA & $r^{2}$ LC/LO & $r^{2} \mathrm{P} / \mathrm{LR}$ & $\mathrm{K}$ & number \\
\hline AMONT & & & & $(C=0.1)$ & (1) & calculated & calculated & of events \\
\hline 1991 & 50 & 23 & 0.85 & 0.35 & 0.89 & 0.98 & 0.64 & 34 \\
\hline 1992 & 60 & 30 & 0.49 & 0.5 & 0.89 & 0.98 & 0.36 & 35 \\
\hline 1993 & 100 & 36 & 0.68 & 0.25 & 0.84 & 0.97 & 0.42 & 29 \\
\hline 1994 & 60 & 30 & 0.84 & 0.28 & 0.94 & 0.97 & 0.68 & 56 \\
\hline 1991-1994 & 56 & 29 & 0.72 & 0.3 & 0.86 & 0.98 & 0.57 & 154 \\
\hline CAL91-94 & 61 & 20 & 0.8 & 0.5 & 0.84 & 0.96 & 0.55 & 77 \\
\hline VAL91-94 & 90 & 40 & 0.89 & 0.4 & 0.94 & 0.97 & 0.6 & 77 \\
\hline 2004 & 50 & 19 & 0.89 & 0.5 & 0.84 & 0.99 & 0.64 & 25 \\
\hline 2005 & 69 & 30 & 0.79 & 0.7 & 0.88 & 0.95 & 0.55 & 33 \\
\hline 2006 & 46 & 25 & 0.93 & 0.3 & 0.84 & 0.99 & 0.78 & 33 \\
\hline 2007 & 35 & 17 & 0.88 & 0.4 & 0.82 & 0.98 & 0.77 & 27 \\
\hline 2008 & 42 & 40 & 0.94 & 0.56 & 0.96 & 1 & 0.83 & 32 \\
\hline 2009 & 42 & 32 & 0.94 & 0.56 & 0.84 & 0.99 & 0.85 & 32 \\
\hline 2010 & 50 & 20 & 0.67 & 0.65 & 0.9 & 0.98 & 0.46 & 34 \\
\hline 2004-2010 & 52 & 32 & 0.89 & 0.4 & 0.87 & 0.99 & 0.74 & 218 \\
\hline CAL04-10 & 46 & 35 & 0.85 & 0.4 & 0.86 & 0.99 & 0.74 & 109 \\
\hline $\begin{array}{c}\text { 1VAL04-10 } \\
\text { AVAL }\end{array}$ & 60 & 31 & 0.95 & 0.45 & 0.87 & 0.98 & 0.74 & 109 \\
\hline 1992 & 95 & 22 & 0.63 & 0.4 & 0.78 & 0.98 & 0.33 & 27 \\
\hline 1993 & 90 & 25 & 0.67 & 0.6 & 0.84 & 0.97 & 0.37 & 29 \\
\hline 1994 & 75 & 20 & 0.85 & 0.6 & 0.94 & 0.96 & 0.52 & 53 \\
\hline 1992-1994 & 75 & 20 & 0.75 & 0.6 & 0.87 & 0.96 & 0.44 & 109 \\
\hline CAL92-94 & 84 & 20 & 0.7 & 0.3 & 0.85 & 0.96 & 0.37 & 55 \\
\hline VAL92-94 & 56 & 25 & 0.66 & 0.6 & 0.89 & 0.98 & 0.52 & 55 \\
\hline 2004 & 45 & 12 & 0.9 & 0.2 & 0.79 & 0.97 & 0.64 & 23 \\
\hline 2005 & 80 & 23 & 0.52 & 0.7 & 0.84 & 0.95 & 0.31 & 35 \\
\hline 2006 & 95 & 33 & 0.81 & 0.7 & 0.86 & 0.97 & 0.52 & 36 \\
\hline 2007 & 105 & 22 & 0.8 & 0.3 & 0.85 & 0.96 & 0.46 & 28 \\
\hline 2008 & 95 & 30 & 0.83 & 0.8 & 0.93 & 0.98 & 0.52 & 32 \\
\hline 2009 & 95 & 20 & 0.83 & 0.9 & 0.79 & 0.99 & 0.71 & 34 \\
\hline 2010 & 60 & 30 & 0.39 & 0.7 & 0.91 & 0.98 & 0.27 & 34 \\
\hline 2004-2010 & 70 & 24 & 0.7 & 0.75 & 0.8 & 0.98 & 0.47 & 222 \\
\hline CAL04-10 & 65 & 30 & 0.58 & 0.6 & 0.83 & 0.98 & 0.43 & 111 \\
\hline 1VAL04-10 & 60 & 20 & 0.75 & 0.7 & 0.79 & 0.99 & 0.52 & 111 \\
\hline
\end{tabular}

HESSD

$8,1569-1607,2011$

\section{Runoff evolution according to land use change}

L. Descroix et al.

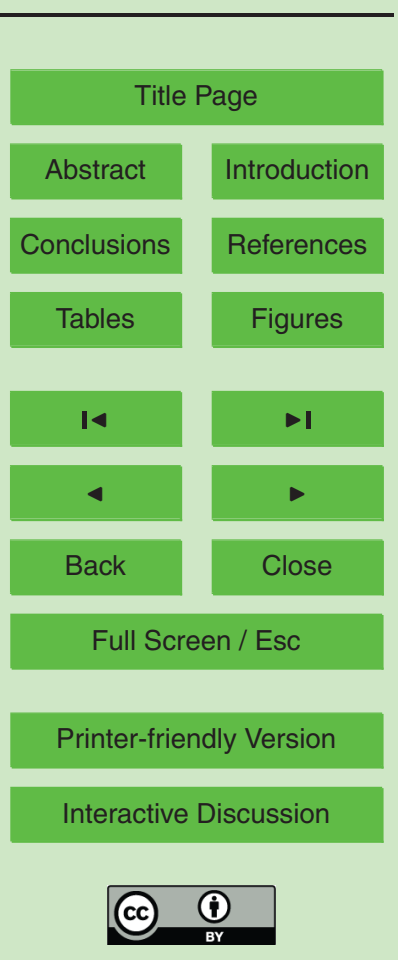




\section{HESSD}

8, 1569-1607, 2011

\section{Runoff evolution according to land use change}

Table B. Continued.

\begin{tabular}{|c|c|c|c|c|c|c|c|c|}
\hline & HMAX & PMAX & KMAX & ALPHA & $r^{2}$ LC/LO & $r^{2} \mathrm{P} / \mathrm{LR}$ & $\mathrm{K}$ & number \\
\hline \multicolumn{9}{|l|}{ BODO } \\
\hline 1991 & 70 & 40 & 0.95 & 0.05 & 0.85 & 0.97 & 0.82 & 36 \\
\hline 1992 & 35 & 21 & 0.48 & 0.8 & 0.69 & 0.99 & 0.39 & 33 \\
\hline 1993 & 80 & 25 & 0.68 & 0.6 & 0.84 & 0.98 & 0.41 & 27 \\
\hline 1994 & 64 & 26 & 0.84 & 0.45 & 0.87 & 0.97 & 0.62 & 39 \\
\hline $1991-1994$ & 62 & 18 & 0.9 & 0.35 & 0.77 & 0.96 & 0.59 & 125 \\
\hline CAL91-94 & 55 & 30 & 0.6 & 0.3 & 0.73 & 0.98 & 0.47 & 76 \\
\hline VAL91-94 & 45 & 35 & 0.8 & 0.3 & 0.79 & 0.98 & 0.71 & 76 \\
\hline 2007 & 95 & 30 & 0.7 & 0.3 & 0.91 & 0.96 & 0.46 & 28 \\
\hline 2008 & 38 & 35 & 1.1 & 0.5 & 0.9 & 0.99 & 0.99 & 32 \\
\hline 2009 & 38 & 40 & 1.1 & 0.5 & 0.85 & 0.99 & 1.02 & 31 \\
\hline 2010 & 40 & 30 & 0.9 & 0.5 & 0.93 & 0.99 & 0.73 & 34 \\
\hline $2007-2010$ & 50 & 30 & 0.9 & 0.8 & 0.92 & 0.98 & 0.68 & 126 \\
\hline
\end{tabular}

L. Descroix et al.

Title Page

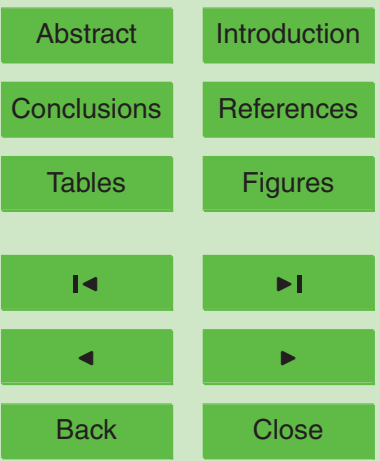

Full Screen / Esc

Printer-friendly Version

Interactive Discussion

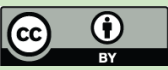




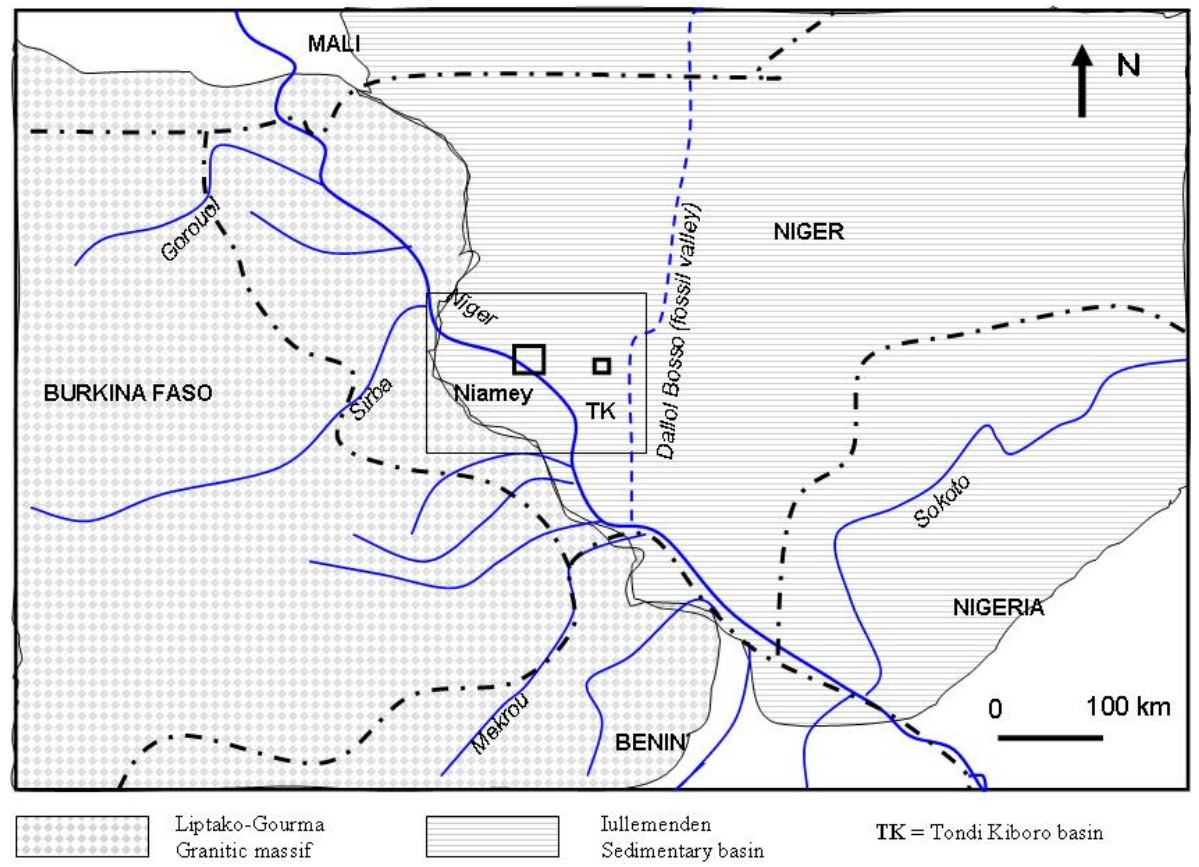

\section{HESSD}

$8,1569-1607,2011$

\section{Runoff evolution according to land use change}

L. Descroix et al.

Title Page

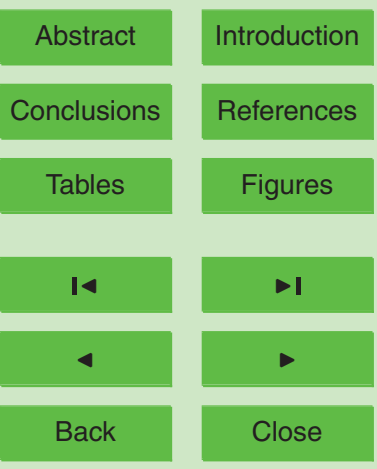

Full Screen / Esc

Fig. 1. Location of the Tondi Kiboro experimental catchment.

Printer-friendly Version

Interactive Discussion 




\section{HESSD}

$8,1569-1607,2011$

\section{Runoff evolution according to land use change}

L. Descroix et al.

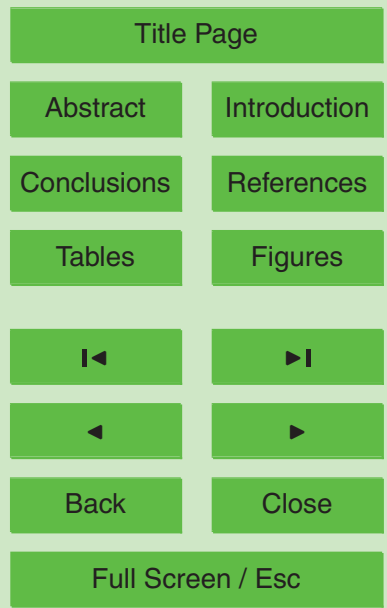

Printer-friendly Version

Fig. 2. Land cover and surface features in the three sub-basins in 1993 and 2007.

Interactive Discussion 


\section{HESSD}

8, 1569-1607, 2011

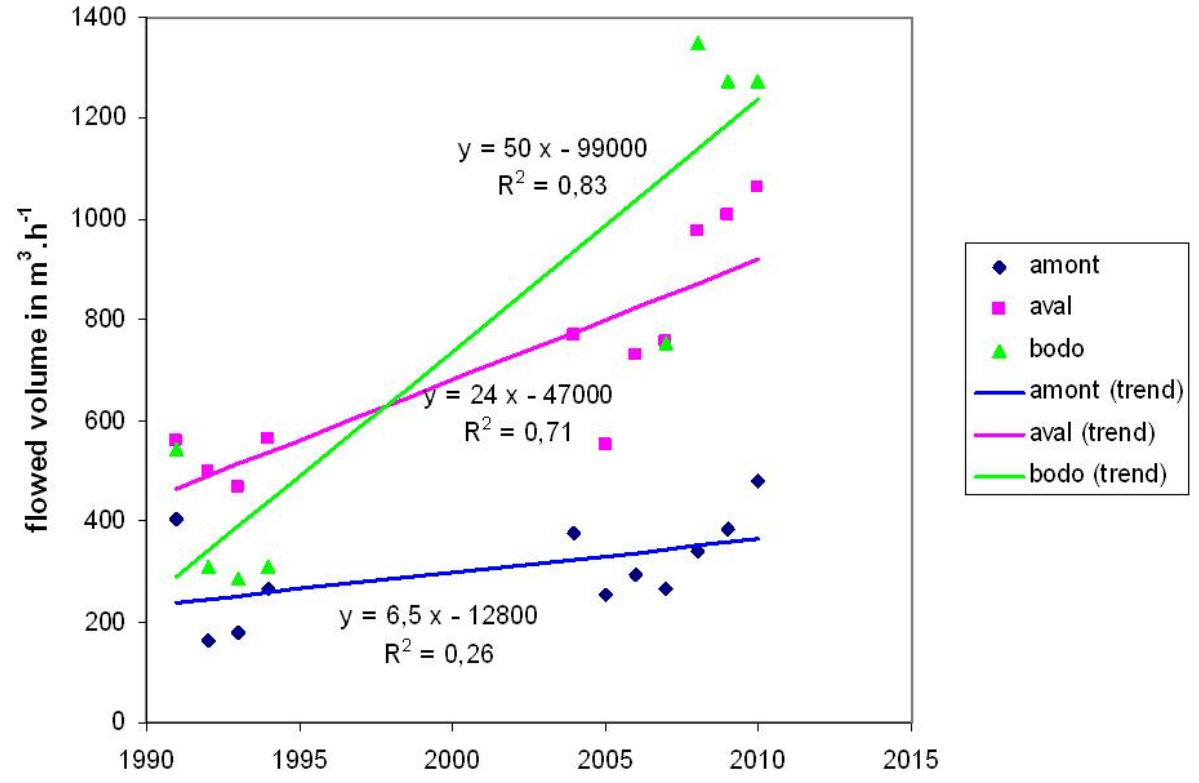

\section{Runoff evolution according to land use change}

L. Descroix et al.

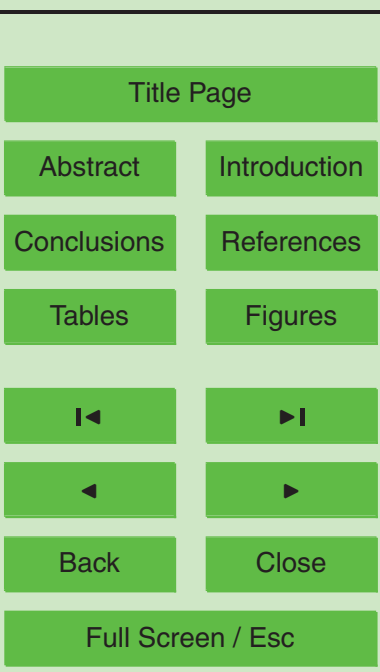

Printer-friendly Version

Interactive Discussion 



\section{HESSD}

$8,1569-1607,2011$

\section{Runoff evolution according to land use change}

L. Descroix et al.

Title Page

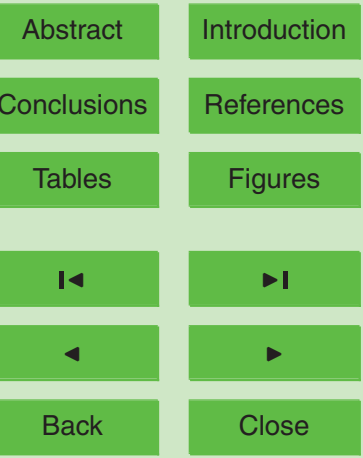

Full Screen / Esc

Printer-friendly Version

Interactive Discussion

Fig. 4. Profiles of neutron probe ratio under the gully (left) and under the fallow (right). 


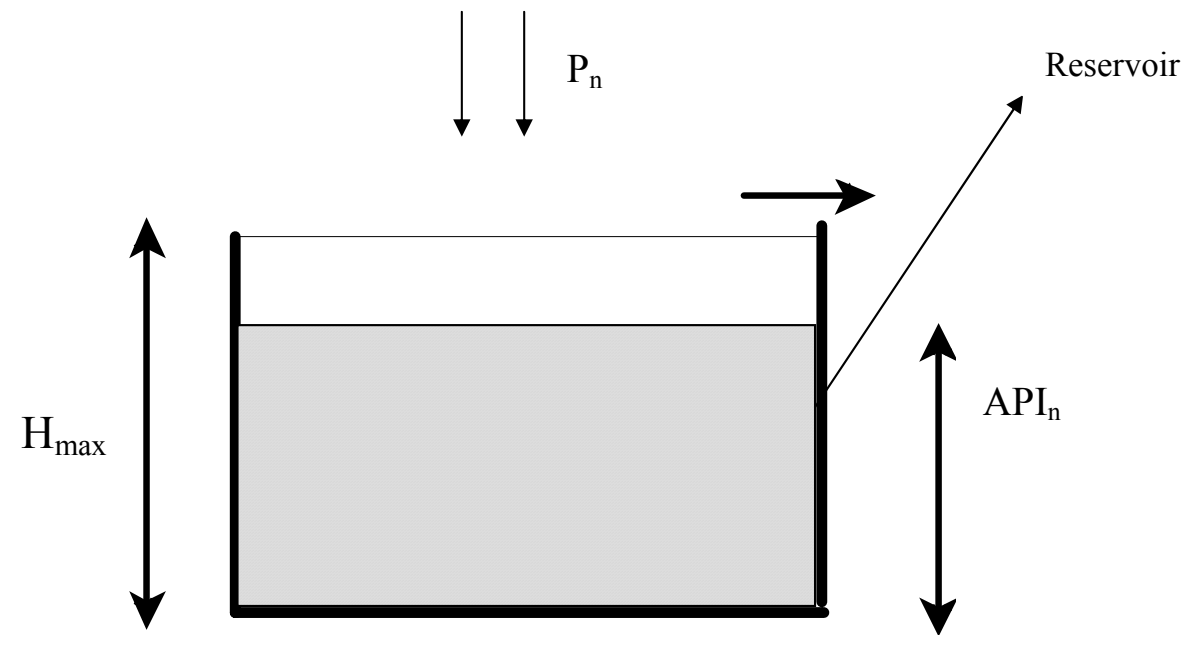

Fig. A1. Description of NAZASM model.

8, 1569-1607, 2011

Runoff evolution according to land use change

L. Descroix et al.

Title Page

Abstract

Introduction

Conclusions

References

Tables

Figures

14

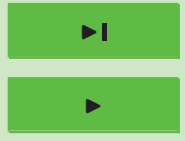

Back

Close

Full Screen / Esc

Printer-friendly Version

Interactive Discussion

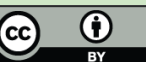

